\title{
Concentrations and fluxes of isoprene and oxygenated VOCs at a French Mediterranean oak forest
}

\author{
C. Kalogridis ${ }^{1}$, V. Gros ${ }^{1}$, R. Sarda-Esteve ${ }^{1}$, B. Langford ${ }^{2}$, B. Loubet ${ }^{3}$, B. Bonsang ${ }^{1}$, N. Bonnaire ${ }^{1}$, E. Nemitz ${ }^{2}$, \\ A.-C. Genard ${ }^{4}$, C. Boissard ${ }^{1}$, C. Fernandez ${ }^{4}$, E. Ormeño ${ }^{4}$, D. Baisnée ${ }^{1}$, I. Reiter ${ }^{5}$, and J. Lathière ${ }^{1}$ \\ ${ }^{1}$ Laboratoire des Sciences du Climat et de l'Environnement (LSCE-IPSL), Unité Mixte CEA-CNRS-UVSQ (Commissariat à \\ l'Energie Atomique, Centre National de la Recherche Scientifique, Université de Versailles Saint-Quentin-en-Yvelines), \\ 91198 Gif-sur-Yvette, France \\ ${ }^{2}$ Centre for Ecology \& Hydrology (CEH), Bush Estate, Penicuik, EH26 0QB, UK \\ ${ }^{3}$ Environnement et Grandes Cultures, INRA, UMR EGC, Thiverval-Grignon, France \\ ${ }^{4}$ Institut Méditerranéen d'Ecologie et Paléoécologie IMEP, 13397 Marseille, France \\ ${ }^{5}$ Aix-Marseille Université, CNRS, ECCOREV FR 3098, Europôle de l'Arbois, 13545 Aix-en-Provence, France
}

Correspondence to: V. Gros (valerie.gros@1sce.ipsl.fr)

Received: 10 December 2013 - Published in Atmos. Chem. Phys. Discuss.: 13 January 2014

Revised: 5 August 2014 - Accepted: 17 August 2014 - Published: 22 September 2014

\begin{abstract}
The CANOPEE project aims to better understand the biosphere-atmosphere exchanges of biogenic volatile organic compounds (BVOCs) in the case of Mediterranean ecosystems and the impact of in-canopy processes on the atmospheric chemical composition above the canopy. Based on an intensive field campaign, the objective of our work was to determine the chemical composition of the air inside a canopy as well as the net fluxes of reactive species between the canopy and the boundary layer. Measurements were carried out during spring 2012 at the field site of the Oak Observatory of the Observatoire de Haute Provence $\left(\mathrm{O}_{3} \mathrm{HP}\right)$ located in the southeast of France. The site is a forest ecosystem dominated by downy oak, Quercus pubescens Willd., a typical Mediterranean species which features large isoprene emission rates. Mixing ratios of isoprene, its degradation products methylvinylketone (MVK) and methacrolein (MACR) and several other oxygenated $\operatorname{VOC}\left(\mathrm{O}_{\mathrm{x}} \mathrm{VOC}\right)$ were measured above the canopy using an online proton transfer reaction mass spectrometer (PTR-MS), and fluxes were calculated by the disjunct eddy covariance approach. The $\mathrm{O}_{3} \mathrm{HP}$ site was found to be a very significant source of isoprene emissions, with daily maximum ambient concentrations ranging between $2-16 \mathrm{ppbv}$ inside and $2-5 \mathrm{ppbv}$ just above the top of the forest canopy. Significant isoprene fluxes were observed only during daytime, following diurnal cycles with midday net emission fluxes from the canopy rang-
\end{abstract}

ing between 2.0 and $9.7 \mathrm{mg} \mathrm{m}^{-2} \mathrm{~h}^{1}$. Net isoprene normalized flux (at $30^{\circ} \mathrm{C}, 1000 \mu \mathrm{mol}$ quanta $\mathrm{m}^{-2} \mathrm{~s}^{-1}$ ) was estimated at $7.4 \mathrm{mg} \mathrm{m}^{-2} \mathrm{~h}^{-1}$. Evidence of direct emission of methanol was also found exhibiting maximum daytime fluxes ranging between 0.2 and $0.6 \mathrm{mg} \mathrm{m}^{-2} \mathrm{~h}^{-1}$, whereas flux values for monoterpenes and others $\mathrm{O}_{\mathrm{x}} \mathrm{VOC}$ such as acetone and acetaldehyde were below the detection limit.

The MVK+MACR-to-isoprene ratio provided useful information on the oxidation of isoprene, and is in agreement with recent findings proposing weak production yields of MVK and MACR, in remote forest regions where the $\mathrm{NO}_{\mathrm{x}}$ concentrations are low. In-canopy chemical oxidation of isoprene was found to be weak and did not seem to have a significant impact on isoprene concentrations and fluxes above the canopy.

\section{Introduction}

Volatile organic compounds (VOCs) are emitted into the atmosphere from natural sources (biogenic emissions) as well as from anthropogenic sources. Biogenic VOCs (BVOCs) constitute approximately $90 \%$ of global VOC emissions (Guenther et al., 1995). These emissions are characterized by a strong chemical diversity with more than a thousand BVOCs identified as emitted by plants. However, only a few 
of them contribute significantly to the global BVOC fluxes into the atmosphere (Laothawornkitkul et al., 2009). Isoprene $\left(\mathrm{C}_{5} \mathrm{H}_{8}\right)$ is the most abundant BVOC in the Earth system, accounting for about half of all natural VOCs emitted at about $10^{15} \mathrm{~g}(\mathrm{C})$ year $^{-1}$ (Guenther et al., 2012). Monoterpenes, sesquiterpenes but also oxygenated compounds, such as methanol, acetone and acetaldehyde may also be important regarding atmospheric chemical processes (Guenther et al., 1995; Kesselmeier et al., 1998; Kesselmeier and Staudt, 1998; Fuentes et al., 2000; Park et al., 2013). Despite their relatively low atmospheric concentrations BVOCs are key components of tropospheric chemistry. Due to their high reactivity, they are rapidly oxidated by agents such as the $\mathrm{OH}$ radicals, thus significantly influencing the oxidizing capacity of the atmosphere and thereby impacting the residence time of air pollutants and the most reactive greenhouse gases such as methane (Wuebbles et al., 1989; Chiemchaisri et al., 2001). BVOCs also play a key role in the tropospheric ozone cycle. In the presence of sufficiently high $\mathrm{NO}_{\mathrm{x}}$ concentrations and light, BVOC emissions may be important precursors of regional-scale $\mathrm{O}_{3}$ (Trainer et al., 1987; Jacob and Wofsy, 1988; Chameides et al., 1988; Lee et al., 2006; Curci et al., 2010). As BVOC emissions increase with ambient light and temperature, the expected progression of climate change may impact BVOC emissions and contribute to regional $\mathrm{O}_{3}$ changes, but several processes still need to be better understood. BVOCs not only influence gas phase atmospheric chemistry; several studies have demonstrated that the oxidation of monoterpenes, sesquiterpenes, and, to a lesser extent, of isoprene, contributes to the formation of secondary organic aerosols (SOAs) in the troposphere (Griffin et al., 1999; Claeys et al., 2004). The contribution estimate of BVOCs to SOA formation is still rather uncertain: (Andreae and Crutzen, 1997) calculated this contribution to be in the range of $30-270 \mathrm{Tg} \mathrm{year}^{-1}$ whereas more recently Tsigaridis and Kanakidou (2003) estimated a smaller range of $2.5-44.5 \mathrm{Tg} \mathrm{yr}^{-1}$.

In the Mediterranean region, the emissions and reactivity of BVOCs are enhanced due to high temperatures and sunny conditions and therefore are of particular interest for the production of $\mathrm{SOA}$ and $\mathrm{O}_{3}$. A modelling study performed by Curci et al. (2010) predicts that, during summer in the Mediterranean region, BVOC emissions may be responsible for an increase of daily $\mathrm{O}_{3}$ maxima by $5 \mathrm{ppbv}$, whereas Richards et al. (2013) estimated that a $20 \%$ cut in local BVOC emissions would lead to an average reduction of only $0.96 \mathrm{ppbv}$ of $\mathrm{O}_{3}$ over the Mediterranean.

To evaluate the contribution of VOCs emitted by vegetation in the Mediterranean area to $\mathrm{O}_{3}$ and SOA formation, a first step is to have accurate information on the amount of BVOCs released into the atmosphere. In this objective, we need to improve our knowledge regarding interactions between the terrestrial biosphere and the atmosphere. These interactions are still poorly understood and quantified. Several experimental studies demonstrated that a potential loss of
BVOCs through chemical reactions and deposition inside the canopy could reduce the net fluxes into the atmosphere ( $\mathrm{Ci}$ ccioli et al., 1999). The loss of isoprene for example, within the canopy, could reach up to $40 \%$ (Makar et al., 1999). A few studies have also used Lagrangian-based stochastic models to explore the effect of chemical degradation of BVOCs inside the canopy (Strong et al., 2004; Rinne et al., 2012). Based on the Lagrangian approach along with measurements of oxidants on a Scots pine site, Rinne et al. (2012) suggested that in-canopy chemical degradation was negligible for isoprene but had a major effect on fluxes of most reactive species such as $\beta$-caryophyllene. Yet, those intra-canopy reactions are generally not considered in global vegetation or chemistry-transport models (Ciccioli et al., 1999; Makar et al., 1999; Fuentes et al., 2000; Forkel et al., 2006). Therefore, there is a need for more experimental data and analysis to quantify the impact of intra-canopy processes, together with a modelling approach in order to evaluate the related error in the estimates of net BVOC fluxes to the Mediterranean atmosphere.

A few studies have determined biogenic net emissions from Mediterranean ecosystems (Seufert et al., 1997; Ciccioli et al., 1999; Darmais et al., 2000; Davison et al., 2009a). During the first BEMA experiment (Biogenic Emissions in the Mediterranean Area 1994) several field campaigns were carried out at the Castelporziano site located on the Mediterranean coast near Rome, with one of the aims being to study BVOC emission fluxes above various Mediterranean species (Velentini et al., 1997). Emissions from orange plantations have also been studied in Spain within the framework of the second BEMA project 1997, and have shown an important loss of very reactive compounds such as sesquiterpenes due to within-canopy removal (Ciccioli et al., 1999) contrary to the low chemical destruction on the less reactive monoterpenes (Darmais et al., 2000).

Among the different tree species that characterize Mediterranean ecosystems, Quercus pubescens Willd. is of particular interest because of its large spatial coverage (being the most important tree species covering $20 \%$ of the vegetated surface, i.e 260000 ha, in the Provence-Alpes-Côte d'Azur region) and high isoprene emission potential. Keenan et al. (2009) estimated that the contribution of $Q$. pubescens to the total European isoprene emissions budget exceeded $15 \%$ for the $1960-1990$ periods. Only a very limited number of BVOC flux measurements have been performed on a $Q$. pubescens ecosystem. Simon et al. (2005) measured fluxes during one day using an aerodynamic gradient method in the forest of Montmeyan, while Baghi et al. (2012) used the disjunct eddy covariance method at the Observatoire de Haute Provence, both studies focusing exclusively on isoprene.

The originality of the CANOPEE ANR-JCJC project is to combine field experiments (branch-scale to canopyscale measurements), targeting a large variety of BVOCs over a $Q$. pubescens forest, with modelling. Experimental data and observations collected during the intensive field 
campaigns will eventually be used in a one-dimensional canopy-chemistry model CACHE (Forkel et al., 2006) and a regional chemistry-transport model, CHIMERE (Schmidt et al., 2001; Szopa et al., 2009). Through these models, both, the in-canopy processes and the role of local forested areas on the atmospheric chemical composition are studied for the Mediterranean region.

Our work consisted in measuring ambient BVOCs inside and above the $\mathrm{O}_{3} \mathrm{HP}$ canopy during an intensive campaign (June 2012). The objectives of this work were (1) to identify and quantify the VOC species locally emitted at the Observatoire de Haute Provence, (2) describe the temporal variation of their mixing ratios, (3) assess net fluxes of BVOC from the canopy to the boundary layer and (4) to discuss the isoprene fluxes and isoprene potential loss due to in-canopy oxidation.

\section{Methodology}

\subsection{Site description and general strategy}

The Observatoire de Haute Provence is an astronomical observatory located in southeastern France $\left(5^{\circ} 42^{\prime} 44^{\prime \prime} \mathrm{E}\right.$, $\left.+43^{\circ} 55^{\prime} 54^{\prime \prime} \mathrm{N}\right)$ on a plateau at a height of about $650 \mathrm{~m}$. The Oak Observatory at the Observatoire de Haute Provence $\left(\mathrm{O}_{3} \mathrm{HP}\right.$, https://o3hp.obs-hp.fr) is an experimental station dedicated to the observation of a deciduous oak ecosystem in relation to climate change. The site, is dominated by downy oak (Q. pubescens Willd) and Montpellier maple (Acer monspessulanum L.) representing 75 and $25 \%$, respectively, of the foliar biomass of the overstorey tree species. The trees are about 70 years old and of an average height of $5 \mathrm{~m}$. Understorey vegetation is dominated by European smoke bush (Cotinus coggygria Scop.) and many thermophilic and xerophilic herbaceous and grass species. The average singlesided leaf area index (LAI) measured (LAI-2000, Li-Cor, Lincoln, NE, USA) in August 2010 is 2.4. Flux footprint, i.e. the area of cumulative contribution to flux, was computed (online at http://www.footprint.kljun.net/) based on stability conditions, measurement height and roughness length (Kljun et al., 2004). Ninety percent of the along-wind footprint was calculated to include an area of $60 \mathrm{~m}$ for low-turbulence conditions $\left(u^{*}=0.2 \mathrm{~m} \mathrm{~s}^{-1}\right.$ and standard deviation of vertical velocity fluctuations, $\sigma_{w}=0.5 \mathrm{~m} \mathrm{~s}^{-1}$ ) and $120 \mathrm{~m}$ for higherturbulence conditions $\left(u^{*}=1.2 \mathrm{~m} \mathrm{~s}^{-1}, \sigma_{w}=1.4 \mathrm{~m} \mathrm{~s}^{-1}\right)$.

The climate is sub-Mediterranean with warm-to-hot, dry summers and mild-to-cool, wet winters. During the field campaign the daily maximum temperatures typically ranged between 18 and $30^{\circ} \mathrm{C}$.

Monthly diurnal isoprene samplings have been conducted at the $\mathrm{O}_{3} \mathrm{HP}$ over an 11-month period in order to characterize seasonal variations of ambient air concentration. During an intensive field campaign from 4 to 16 June 2012, measurements of $\mathrm{BVOC}, \mathrm{NO}_{\mathrm{x}}$ and ozone concentrations, as well as flux measurements of individual VOC species, were per- formed. In addition to atmospheric measurements, BVOC emission rates at the branch scale were measured using dedicated chambers, and are described in the companion paper (Genard-Zielinksi et al., 2014).

\subsection{Monthly isoprene sampling on cartridges and GC-MS analysis}

Prior to the intensive field campaign, the seasonal variation of isoprene was followed inside the canopy. Air samples were collected on a monthly basis between May 2011 and December 2011 and from April 2012 to June 2012. Air was collected onto cartridges using an autosampler (SASS, TERA Environnement, Crolles, France). Commercially packed cartridges consisted of stainless-steel tubes filled with Tenax TA adsorbents. For a single sequence, 12 cartridges collected a volume of $700 \mathrm{~mL}$ of air during $2 \mathrm{~h}$. The air entering the cartridge was filtered in order to eliminate any particulate matter. Each sampling tube was kept refrigerated at $4{ }^{\circ} \mathrm{C}$ and analysed at the laboratory within a month. The GC-MS analysis system consisted of an automatic desorption system (ATD 300, TurboMatrix, Perkin Elmer), coupled to a GC (Varian Model 3800, Varian Inc., USA) linked to an ion trap mass spectrometer from the same company. Blank cartridges were analysed every three or five samples and showed no significant levels of isoprene. An external multi-point calibration was performed by doping the adsorbent tubes with a VOC standard (National Physical Laboratory, Teddington, Middlesex, UK). The quantification limit was less than 140 pptv.

\subsection{Ambient air sampling system during the intensive field campaign}

Ambient air sampling was conducted at two different heights: $2 \mathrm{~m}$ above ground level (a.g.l.) inside the canopy, and above the top of the canopy at about $10 \mathrm{~m}$. Both sampling inlets were slightly heated to about $1^{\circ} \mathrm{C}$ above ambient temperature with a thermocouple type $\mathrm{K}$ in order to prevent water condensation. The lines were protected from radiation and attached to a pump-up mast, situated at $30 \mathrm{~m}$ from the van where all instruments were housed.

At $2 \mathrm{~m}$ a.g.l., air was pulled through a $35 \mathrm{~m}$ Teflon line (PFA, 1/2" outside diameter "OD" and 3/8" inner diameter "ID") at about $40 \mathrm{~L} \mathrm{~min}^{-1}$. Side flows were taken from a manifold at the end of the main line through thinner Teflon lines (PFA, 1/4" OD, 5/32"ID) and sub-sampled by a range of gas analysers (GC-FID, $\mathrm{NO}_{\mathrm{x}}$ and ozone analysers).

At $10 \mathrm{~m}$ a.g.l, air was pulled through a $45 \mathrm{~m}$ Teflon line (PTFE, 1/2" OD, 3/8" ID) at a higher flow $\left(\sim 64 \mathrm{~L} \mathrm{~min}^{-1}\right)$ in order to maintain the turbulent flow (Reynolds number $=9440$ ) needed to minimize signal attenuation. A proton transfer reaction mass spectrometer (PTR-MS) and a $\mathrm{CO}_{2} / \mathrm{H}_{2} \mathrm{O}$ analyser (IRGA LI-7500, Li-Cor, Lincoln, NE, USA) sub-sampled continuously at a flow rate of 80 and 
$5 \mathrm{~L} \mathrm{~min}^{-1}$ respectively. The displacement between the inlet and the sonic anemometer (HS-50 Hz, Gill Instruments Ltd., Hampshire, UK) was about $20 \mathrm{~cm}$ horizontally and $5 \mathrm{~cm}$ vertically. The representation of the tilt angle of the sonic anemometer as a function of wind speed showed no significant disturbance from the air motion within the detection region of the anemometer.

\subsection{BVOC measurement using proton transfer reaction mass spectrometer}

\subsubsection{PTR-MS operation}

Concentrations and fluxes of VOCs above the canopy were processed in the real time with a PTR-MS (serial number: 10-HS02 079, 2010, Ionicon Analytik, Innsbruck Austria), a technique which has been described in recent reviews (De Gouw and Warneke, 2006; Blake et al., 2009) and references therein. Briefly, the PTR-MS used was a high-sensitivity Ionicon model. We operated the drift tube at $2.2 \mathrm{mbar}$ pressure, $60{ }^{\circ} \mathrm{C}$ temperature and $600 \mathrm{~V}$ voltage, to achieve an $E / N$ ratio of approximately $132 \mathrm{Td}(E$ : electric field strength $\left[\mathrm{V} \mathrm{cm}^{-1}\right], N$ : buffer gas number density [molecule $\mathrm{cm}^{-3}$ ]; $1 \mathrm{Td}=10^{-17} \mathrm{~V} \mathrm{~cm}^{2}$ ). The primary $\mathrm{H}_{3} \mathrm{O}^{+}$ion count assessed at $m / z 21$ ranged between $0.9 \times 10^{7}-1.9 \times 10^{7} \mathrm{cps}$ with a typically $<5 \%$ contribution from the monitored first water cluster at $m / z \quad 37$ and $<4 \%$ contribution from the oxygen $\mathrm{O}_{2}^{+}$at $m / z 32$.

A first series of measurements in scan mode enabled us to browse a wide range of masses $(m / z 21-m / z$ 206) and to set the PTR-MS measurement procedure for the rest of the field campaign. Above $m / z$ 93, the only significant signal observed was at $m / z 137$.

The PTR-MS measurement procedure consisted of an hour-long sequence. In order to provide both flux data and information on the full VOC composition, the PTR-MS was automatically set to run continuously in two different modes: twice $25 \mathrm{~min}$ in flux mode and twice $5 \mathrm{~min}$ in scan mode during each hour. During the flux mode, eight protonated target masses $(\mathrm{m} / \mathrm{z} 33,45,59,61,69,71,87$ and 137) were measured successively with a dwell time of $500 \mathrm{~ms}$ per mass, while the primary ion count $(\mathrm{m} / \mathrm{z} 21)$, the first water cluster ion count $(m / z 37)$ and the photon "dark counts" $(m / z 25)$ were all measured with a dwell time of $200 \mathrm{~ms}$. This resulted in a total cycle time of $4.6 \mathrm{~s}$ and a total of $n \approx 326$ recorded values per $25 \mathrm{~min}$ flux period. The remaining $10 \mathrm{~min}$ of each hour were used to obtain basic concentration information across the mass spectrum $(5 \mathrm{~min})$, and to monitor the instrument background (5 min). The PTR-MS background for each mass was monitored by sampling zero air (Ionimed's GCU zero air generator) and was subtracted during postprocessing. As each scan mode was set to $5 \mathrm{~min}$ and to a dwell time of $500 \mathrm{~ms}$, the mass range was limited to $\mathrm{m} / \mathrm{z} 21-$ 93 , in order to have at least five data points for each mass per cycle.
PTR-MS data were stored alongside those from the sonic anemometer, using a custom logging program written in LabVIEW (National Instruments, Austin, Texas, USA) as previously implemented by Langford et al. (2009).

\subsubsection{Calibration and volume mixing ratio (VMR) calculations}

The PTR-MS was calibrated on the first and the last days of the field campaign using a Gas Calibration Unit (GCU, Ionimed Analytik GmbH, Innsbruck, Austria), a dynamic gas dilution system that provides defined and controllable concentrations of different VOC using VOC-free air produced from ambient air with the GCU catalyst (Singer et al., 2007). The commercial internal gas canister provided by Ionimed contained a mixture of 17 VOCs. The species used for the calibration were methanol (contributing to $m / z 33$ ), acetaldehyde $(m / z 45)$, acetone $(m / z 59)$, isoprene $(m / z 69)$, crotonaldehyde $(m / z 71), 2$-butanone $(m / z 73)$, benzene $(m / z 79)$, toluene $(m / z$ 93) and $\alpha$-pinene $(m / z 137)$. The VOC concentrations in the standard gas were diluted (eight dilution steps) from an initial mixing ratio of 1 ppmv to a mixing ratio of 20 ppbv. Calibration coefficients, also called normalized sensitivities $\left(S_{\text {norm }}\right)$ were calculated for each atomic mass unit (amu, $m / z$ ) using the approach of Taipale et al. (2008). As methylvinylketone (MVK) and methacrolein (MACR) were not included in the gas standard, we used the sensitivity of their structural isomer crotonaldehyde. The sensitivity of $\alpha$ pinene was used for the sum of total monoterpenes. Sum of monoterpenes have been commonly quantified based on both molecular ion $(m / z 137)$ and fragment ions $(m / z 81)$. In this study, total monoterpenes were only calibrated against $m / z$ 137. As considerable monoterpene fragmentation is expected for an $E / N$ ratio of $132 \mathrm{Td}$, the abundance of the molecular ion $(m / z 137)$ is expected to decline in favour of the fragment ions (dominant at $\mathrm{m} / z$ 81). Also, as fragmentation patterns are dependent on the different monoterpenes species present, the sensitivity of $m / z 137$ can slightly change if the monoterpenes composition is variable (Misztal et al., 2013). Nevertheless, additional measurements performed with cartridges have shown that $\alpha$-pinene was the dominant terpene $(80 \pm 13 \%)$ and therefore calculated sensitivity of total monoterpene from $\mathrm{m} / \mathrm{z} 137$ is justified (see the Supplement).

The differences in sensitivities from the two PTR-MS calibrations were below $5 \%$ for the compounds most discussed in the paper (methanol, acetaldehyde, acetone, isoprene and MVK +MACR). Higher differences of 9.36, 12.51 and $20.19 \%$ were observed for benzene, toluene and monoterpenes respectively.

The mean values of normalized sensitivities determined from both gas calibration are given in Table 1, together with the detection limits, calculated as two times the standard deviation of the normalized background counts when measuring from the catalytically converted "zero" air. For 
Table 1. Normalized sensitivities derived from the gas calibration. Limit of detections calculated as two times the standard deviation of the noise (ncps) divided by the normalized sensitivity.

\begin{tabular}{|c|c|c|c|}
\hline \multirow[b]{2}{*}{$m / z$} & \multicolumn{3}{|c|}{ VOC present in the calibration gas standard } \\
\hline & $\begin{array}{l}\text { Identified } \\
\text { compound }\end{array}$ & $\begin{array}{r}S_{\text {norm }}\left(\text { ncps ppbv }{ }^{-1}\right) \\
(\text { dwell }=0.5 \mathrm{~s})\end{array}$ & $\begin{array}{r}\text { LOD } \\
(\mathrm{ppbv})\end{array}$ \\
\hline 33 & Methanol & 17.2 & 0.31 \\
\hline 45 & Acetaldehyde & 21.6 & 0.13 \\
\hline 59 & Acetone & 22.9 & 0.05 \\
\hline 69 & Isoprene & 9.8 & 0.07 \\
\hline 71 & Crotonaldehyde & 27.4 & 0.03 \\
\hline 79 & Benzene & 11.8 & 0.04 \\
\hline 93 & Toluene & 12.4 & 0.07 \\
\hline 137 & $\alpha$-Pinene & 4.0 & 0.04 \\
\hline
\end{tabular}

methanol, instrument background counts were generally high and therefore the ambient measurement signal was relatively high as well. However, all data points for methanol, and also acetone exceeded the detection limit. Approximately $9 \%$ of $\mathrm{m} / \mathrm{z} 45,15 \%$ of $\mathrm{m} / \mathrm{z} 71,20 \%$ of $\mathrm{m} / z 73$ and $\mathrm{m} / \mathrm{z} 75$ and $35 \%$ of $\mathrm{m} / z 61$ data points were below the detection limits, usually found at night or just before sunrise. As the background counts of $m / z 137$ were not measured in the scan mode, they were derived from the calibrations, when the instrument was zeroed with catalytically converted air. The dwell time on each mass was $2000 \mathrm{~ms}$ during the calibration (instead of $500 \mathrm{~ms}$ during ambient measurements), thus, the background at $m / z 137$ might have been slightly underestimated. Ambient mixing ratios of monoterpenes followed at $\mathrm{m} / \mathrm{z}, 137$ ranged between 0 and $0.26 \mathrm{ppb}$ and only $58 \%$ of the data points exceeded the detection limits.

Various techniques for statistical analysis of data below the detection limits have been developed and used. Most of these methods have advantages and disadvantages. A simple approach, commonly used, consists in replacing values below the Limit of Detection (LOD), with one-half their respective detection limits (Clarke, 1998). However, this substitution method can result in bias, either high or low depending on the value substituted (Helsel and Hirsch, 1992). In this study, all the compounds were considered representative in their full data set, and no data points have been removed or substituted.

\subsubsection{Identification of VOC and mass interferences}

Standard PTR-MS instruments operate with a unit mass resolution and therefore cannot easily distinguish isobaric molecules. Furthermore, the formation of cluster ions and fragmentation of product ions may complicate the interpretation of PTR-MS mass spectra.
Isoprene for example, can fragment in the PTR-MS instrument and yield $m / z$ 41. During this study, the fragmentation of isoprene in the PTR-MS instrument was small: more than $80 \%$ remained on the parent ion $(\mathrm{m} / z 69)$. Considering that the $m / z, 69$ to $m / z 41$ ratio is constant (for a fixed $E / N$ value), quantification of isoprene based on $\mathrm{m} / z 69$ should not be affected by fragmentation.

Isoprene can suffer from interference with isomers such as furans (Christian et al., 2004). However, as the site is not impacted by significant sources of anthropogenic pollution, furan interference was expected to be negligible. Eventually, fragments of 2- and 3-methyl butanal and 2-methyl-3-buten2-ol (MBO) can also contribute to the ion channel $\mathrm{m} / z 69$. Despite the possibility of these multiple interferences at $m / z$ 69, an inter-comparison showed a good agreement between PTR-MS and GC-FID, with a difference within the uncertainty range of both instruments (see Sect. 2.7). Considering the magnitude of isoprene emissions, it is very unlikely that any interference was significant.

As the GC-FID system deployed during the field campaign was designed for measuring exclusively hydrocarbons, no intercomparison with the PTR-MS was possible for the compounds attributed to $\mathrm{C} 2-\mathrm{C} 6 \mathrm{O}_{\mathrm{x}}$ VOC. For these compounds the discussion of potential interferences is therefore based on the literature.

Methanol, detected at $m / z 33$, is expected to exhibit only little fragmentation but can suffer from interferences with the oxygen isotope ${ }^{16} \mathrm{O}^{17} \mathrm{O}$ detected at the same mass (De Gouw and Warneke, 2007; Taipale et al., 2008). Minimal interferences are also expected at $m / z 45$, which is attributed to acetaldehyde. Acetone and propanal are both detected at $m / z 59$ in PTR-MS, but previous studies showed that the contribution from propanal is typically only small $(0$ $10 \%$ ) (De Gouw and Warneke, 2006) and confined to urban and industrial areas; the measurement at $\mathrm{m} / \mathrm{z} 59$ can therefore be regarded as a measurement of acetone. Signals at $m / z$ include mainly acetic acid and glycolaldehyde but can also suffer interferences from ethyl acetate fragments originated from industrial emissions (Christian et al., 2004; De Gouw and Warneke, 2007; Haase et al., 2012; Yuan et al., 2013) The isomers methylvinylketone (MVK) and metacrolein (MACR) were detected at the same mass-tocharge ratio, $m / z 71$. Until recently, the $\mathrm{C}_{4} \mathrm{H}_{7} \mathrm{O}^{+}$ions have been exclusively attributed to the sum of the former compounds (Blake et al., 2009; De Gouw and Warneke, 2007). New evidence suggests additional contribution from other isoprene oxidation products, believed to be mostly organic hydroperoxides, that fragment at the same $\mathrm{m} / z$ ratio as the product ions of MVK and MACR, especially for low- $\mathrm{NO}_{\mathrm{x}}$ conditions (Liu et al., 2013). As isoprene hydroperoxides are expected to have similar diurnal variability to MVK and MACR, it is particularly difficult to estimate the contribution of isoprene hydroperoxides to $m / z 71$. Thus, we have to keep in mind that the concentration attributed to MACR and MVK might be slightly overestimated. 
The major contribution at mass channel $\mathrm{m} / \mathrm{z} 73$ is expected to originate from methylethylketone and methylpropanal, whereas the signal at $\mathrm{m} / \mathrm{z} 75$ could correspond to hydroxyacetone (Karl et al., 2007). However, potential interferences have been previously reported from butanal at $m / z 73$ and butanol and propionic acid at $m / z 75$ (De Gouw and Warneke, 2007; Karl et al., 2009) and no further investigation was made during this work to quantify these potential interferences. Total monoterpenes can be detected predominantly on the parent $\mathrm{m} / \mathrm{z} 137$ and the fragment $\mathrm{m} / \mathrm{z} 81$ ions. In this study, monoterpene concentrations were calculated based on the $m / z 137$ signal.

\subsection{Flux calculations}

Flux measurements of individual VOC species were performed using the micrometeorological disjunct eddy covariance by mass-scanning (DEC-MS) method, also referred to as the virtual disjunct eddy covariance technique (vDEC). DEC-MS and the conventional eddy covariance (EC) method rely on the same principle - that is, when the boundary layer is fully turbulent, the net vertical transfer is due to eddies. The flux of each compound is therefore calculated as the covariance between the vertical wind speed $(w)$ and the VOC mixing ratio $(c)$ :

$F=\frac{1}{n} \sum_{i=1}^{n} w^{\prime}\left(i-t_{\mathrm{lag}} / \Delta_{t w}\right) \cdot c^{\prime}(i)$,

where $w^{\prime}(=w-\bar{w})$ and $c^{\prime}(=c-\bar{c})$ are the instantaneous fluctuations about the mean vertical wind and the mean VOC concentration respectively, $n$ is the number of PTR-MS measurements during each $25 \mathrm{~min}$ averaging period (here, $n=326), t_{\text {lag }}$ is the variable lag time that exists between wind and PTR-MS measurements resulting from the sample transit through the sampling line, and $\Delta_{t w}$ is the sampling interval of the vertical wind velocity measurements $(20 \mathrm{~Hz}=0.05 \mathrm{~s})$.

Further details can be found in Rinne et al. (2001), Karl et al. (2002) and Langford et al. (2009). Output files from the logging program containing $30 \mathrm{~min}$ arrays of wind and PTR-MS data ( $25 \mathrm{~min}$ ) were post-processed by an algorithm written in LabVIEW by Langford et al. (2009) in order to calculate the VOC fluxes. Each data row corresponding to a given VOC was converted to ppbv and to $\mathrm{g} \mathrm{m}^{-3}$ using temperature and pressure values recorded at the site. Next, each VOC concentration data $(c)$ was paired with the corresponding vertical wind velocity $(w)$. The lag time between $(w)$ and $(c)$ resulting from the sample residence time in the sampling line was variable due to fluctuations of temperature and pressure. For each $25 \mathrm{~min}$ period, lag time ( $\left.t_{\text {lag }}\right)$ was automatically determined for each compound using the maximum covariance method between the VOC concentration (c) and the vertical wind speed $(w)$ (Taipale et al., 2010). For isoprene, a maximum covariance typically occurred around $15 \pm 0.6 \mathrm{~s}$. Based on isoprene results, MVK+MACR maximum covariance was searched within a window between 14 and $16 \mathrm{~s}$. Due to its sticky nature, methanol showed slightly longer lag times with a mean value of $16.2 \pm 1.4 \mathrm{~s}$. The experimental mean time lag of each compound was used as the default value when we found no maximum in the covariance function. The post-processing algorithm also filtered out data which did not meet specific quality criteria:

1. VOC flux data recorded during periods of low turbulence. The lower limit of friction velocity $u_{*}$ was set to $0.15 \mathrm{~m} \mathrm{~s}^{-1}$, a threshold commonly used in eddy covariance routine tests (Langford et al., 2010; Misztal et al., 2011).

2. VOC flux values below the detection limit. The detection limit was calculated as three times the standard deviation of the covariance for $t_{\text {lag }}$ far away from the true lag (+150-180 s) (Spirig et al., 2005).

3. Non-stationary data. A stationary test, as suggested for the first time by Foken and Wichura(1996), was applied where the 25 min flux was disaggregated into 5 min blocks and the average of these compared to the 25 min flux. When the difference $(\Delta s)$ between the average of the $5 \mathrm{~min}$ blocks and the $25 \mathrm{~min}$ flux was above $60 \%$, data were considered as non-stationary. Time series where the fluxes differed between 30 and $60 \%$ were considered stationary, but of low quality. When the fluxes differed by less than $30 \%$, the data were considered as high-quality stationary data.

In the current study, $30 \%$ of isoprene, $29 \%$ of methanol and $60 \%$ of MVK+MACR data points were rejected. Of the data that passed the quality assessment, more than $80 \%$ were ranked as high quality. More statistics about these tests are presented in Table 3.

BVOC fluxes were corrected for high-frequency losses using the following equation:

$$
\begin{aligned}
F_{\text {non-attenuated }} & =F_{\mathrm{m}} \cdot f_{\mathrm{c}} \\
& =F_{\mathrm{m}} \cdot\left(1+\left(\left(2 \pi \times \tau \times n_{\mathrm{m}} \times \bar{u}\right) /(z-d)\right)^{a}\right),
\end{aligned}
$$

where $F_{\mathrm{m}}$ is the measured flux, $F_{\text {non-attenuated }}$ is the nonattenuated flux, and $f_{\mathrm{c}}$ the correction factor (Horst, 1997; Davison et al., 2009b). $f_{\mathrm{c}}$ was calculated as a function of $\tau$, the response time of the PTR-MS (here $0.5 \mathrm{~s}$ ), $z$ the measurement height $(10 \mathrm{~m}), d$ the displacement height $\left(2 / 3, h_{\mathrm{c}}\right.$, where $h_{\mathrm{c}}$ is the canopy height, and $\bar{u}$ the average wind speed at the measurement height. For neutral and unstable stratification, the dimensionless frequency at the co-spectral maximum is $n_{\mathrm{m}}=0.085$ and $=7 / 8$. Over the whole measurement period, the attenuation correction ranged from 1.1 to $23 \%$, with a mean value of $13 \%$.

Eventually, the error introduced by disjunct sampling was estimated by comparing sensible heat fluxes calculated from continuous data with sensible heat fluxes calculated from disjunct series. In order to simulate the disjunct sampling protocol on sensible heat data, a LabVIEW routine was used to 
average the wind and temperature data to match the sampling rate of the PTR-MS $(2 \mathrm{~Hz})$ and set the sampling interval to $4.6 \mathrm{~s}$. The difference between EC and DEC heat fluxes was small, typically below $2 \%$. Assuming similarity between the heat flux and our VOC flux, a $2 \%$ error was estimated and no additional corrections have been made on the VOC fluxes.

\subsection{VOC measurements by gas chromatography}

An automatic gas chromatograph (airmoVOC C2-C6, Chromatotec, Saint Antoine France) equipped with a flame ionization detector (GC-FID) suitable for the measurement of light hydrocarbons, especially for isoprene, sampled at $2 \mathrm{~m}$ a.g.l. For each half-hour analysis, $250 \mathrm{~mL}$ of ambient air was drawn into the system via a stainless-steel inlet line with a flow rate of $18 \mathrm{~mL} \mathrm{~min}^{-1}$ (air sample integrated over $10 \mathrm{~min}$ ). The air sample passed first through a Nafion dryer in order to remove the humidity and then hydrocarbons were pre-concentrated on a trap filled with Carboxen, Carbopack B and Carbotrap C. The trap was cooled to $-8^{\circ} \mathrm{C}$ by a cell with Peltier unit during the sampling procedure. Then, the pre-concentrated air sample was thermally desorbed at $220^{\circ} \mathrm{C}$ and injected on-column into a metal capillary column (Porous Layer Open Tubular Column PLOT, $\mathrm{Al}_{2} \mathrm{O}_{3} / \mathrm{KCl}$; $0.53 \mathrm{~mm}$ inner diameter and $25 \mathrm{~m}$ length, Varian Inc) located inside the heated oven of the GC. The column temperature was programmed to maintain $40^{\circ} \mathrm{C}$, and then to heat up at a rate of $20^{\circ} \mathrm{C} \mathrm{min}^{-1}$ up to a final temperature of $203^{\circ} \mathrm{C}$. Non-oxygenated $\mathrm{C}_{2}-\mathrm{C}_{6}$ hydrocarbons (mainly isoprene during the measurements) were finally detected and quantified by a FID. A certified standard gas mixture (National Physical Laboratory, Teddington, Middlesex, UK) containing a mixture of 17 VOC at about 4 ppbv, was used as calibration standard. A complete calibration was performed twice a week. Each calibration was repeated at least three times in order to test the repeatability of the measurement. Relative standard deviations for analysis of the calibration mixtures were in the range of $1-9 \%$. The overall uncertainty was estimated to be better than $15 \%$.

\subsection{GC-FID/PTR-MS isoprene field comparison}

An in situ comparison was carried out during the campaign between isoprene measurements by GC-FID and PTR-MS. Both instruments sampled air from the same line at $2 \mathrm{~m}$ a.g.l. The GC-FID integrated air sample over $10 \mathrm{~min}$ every $30 \mathrm{~min}$. By contrast, the PTR-MS sampled air continuously and followed isoprene at $m / z 69$ with a dwell time of $500 \mathrm{~ms}$ and a total cycle analysis of about $1 \mathrm{~min}$. Only samples for which the GC-FID sample trapping interval and the PTR-MS sample cycle overlapped were included and the PTR-MS measurement were averaged over the 10 min sampling integration of the GC-FID. As this exercise lasted $19 \mathrm{~h}$, in total 38 points were used for this intercomparison. Overall a very good correlation was observed between both instruments
$\left(R^{2}=0.92\right)$, with $10 \%$ higher values for the GC-FID, a difference which is within the uncertainty range. The intercomparison highlighted an average offset of $+0.3 \mathrm{ppbv}$ for the PTR-MS during night-time, which was not subtracted from the PTR-MS data points and may be due to interferences from other VOCs. This night-time offset has to be kept in mind but remains small compared to the average daytime isoprene concentrations ( $2.09 \mathrm{ppbv})$.

\section{8 $\mathrm{NO}_{\mathrm{x}}$, ozone and micrometeorological measurements}

Nitrogen oxides $\left(\mathrm{NO}_{\mathrm{x}}\right)$ and ozone concentrations were measured $2 \mathrm{~m}$ a.g.l. A flow of $920 \mathrm{~mL} \mathrm{~min}^{-1}$ was sub-sampled from the main line and directed to the $\mathrm{NO}_{\mathrm{x}}$ analyser. $\mathrm{Ni}$ trogen oxides were monitored with a T200UP instrument (Teledyne Advanced Pollution Instrumentation, San Diego, California, USA) by ozone-induced chemiluminescence. A 30 min span calibration was performed every day using a dynamic dilution calibrator (T700 UP, API, USA) equipped with a programmable NO generator. The span calibration was automated to run $15 \mathrm{~min}$ of zero air (produced by the zero air generator $\mathrm{T} 701 \mathrm{H}$, API) followed by $15 \mathrm{~min}$ of $\mathrm{NO}$ measurements generated at $5 \mathrm{ppbv}$. A calibration at $10 \mathrm{ppbv}$ of $\mathrm{NO}$ was performed once a week by measuring $30 \mathrm{~min}$ of zero air and $30 \mathrm{~min}$ of a certified standard gas mixture (Air Liquide, Cofrac certification).

Ozone was measured with an automatic ultraviolet absorption's analyser API T400 (API, USA) which was calibrated prior to the field deployment with an internal ozone generator (IZS, API) and operated with a sample flow rate of approximately $740 \mathrm{~mL} \mathrm{~min}^{-1}$.

Meteorological parameters such as temperature and air humidity (CS215, Campbell Scientific, UK) as well as photosynthetically active radiation, PAR (LI-190, Li-Cor, Lincoln, NE, USA), profiles inside the canopy were continuously monitored. The sonic anemometer (HS-50 Hz, Gill Instrument, Hampshire, UK) enabled the measurement of wind speed and direction and to calculate the friction velocity $u_{*}$.

\section{Results}

\subsection{Ambient isoprene seasonal variations}

Figure 1 depicts the diurnal and seasonal variations of ambient, in-canopy, isoprene concentrations at the $\mathrm{O}_{3} \mathrm{HP}$ from May 2011 until May 2012. One or two complete diurnal cycles were taken every month. Even if the values reported here are representative only for the specific sampling days, significant seasonal variations of isoprene concentration were observed and were in agreement with the dependency of isoprene emission as a function of ambient light and temperature (Guenther et al., 1993). As conditions have been warmer in springtime than in summertime, maximum isoprene concentrations have been observed at the end of May with a maximum value of $8 \mathrm{ppbv}$. Lower concentrations were measured 


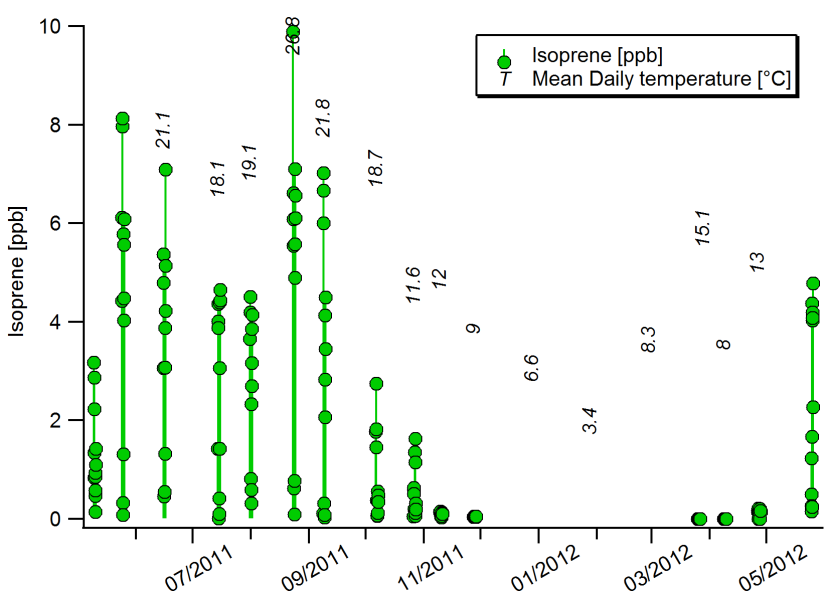

Figure 1. Seasonal variation of isoprene concentrations ( $3 \mathrm{~m}$ a.g.1.) at the $\mathrm{O}_{3} \mathrm{HP}$, May to December 2011 and from April to June 2012. Measurement derived from cartridge samples and analysed by GCMS.

on 14 and 31 July (maximum values of $4-5 \mathrm{ppbv}$ ) followed by a new increase in the end of August (9.8 ppbv); concentrations then decreased during the autumn when the leaves of the downy oak were still persistent and no significant isoprene concentration above detection limit was detected after November.

\subsection{Air chemical regime}

During the campaign the $\mathrm{O}_{3} \mathrm{HP}$ site was typically under the influence of northerly wind regime. As depicted in Fig. 2, air masses were usually transported from the (north) western part of France and only some sparse events of southern winds occurred (5-7 June, 14-16 June). Very low NO levels $(<0.2 \mathrm{ppbv})$ were detected and no significant influence from anthropogenic $\mathrm{NO}_{\mathrm{x}}$ was observed $\left(\mathrm{NO}_{2}<3 \mathrm{ppbv}\right)$. Likewise, $\mathrm{CO}$ concentrations were low throughout the study (<180 ppbv). Benzene and toluene measurements, detected and used as tracers of anthropogenic pollution, showed background levels below $0.2 \mathrm{ppbv}$ with the exception of one brief episode (7 and 8 June) when their concentration reached 0.8 and $1.6 \mathrm{ppbv}$ (Fig. 3). During this episode the benzene-totoluene ratio was slightly lower than for the rest of the measurement period and ranged between 0.3 and 0.8 , indicating an influence of fresh anthropogenic air masses. As benzene and toluene have different lifetimes, the higher the benzeneto-toluene ratio the older is the air mass. Globally, the air masses encountered were not significantly impacted by anthropogenic primary emissions.

Relatively high ozone concentrations, typical of regions with strong photochemical activity such as the Mediterranean Basin, have been registered, with daily maximum ranging between 40 and $76 \mathrm{ppb}$.

\subsubsection{Isoprene mixing ratios and above-canopy fluxes}

The May-June 2012 time series of isoprene mixing ratios recorded simultaneously at $2 \mathrm{~m}$ (inside the canopy by GCFID) and at $10 \mathrm{~m}$ height (above the canopy by PTR-MS) are shown in Fig. 3 along with air temperature and wind conditions. Isoprene exhibited high concentrations with an average mixing ratio of $1.2 \mathrm{ppbv}$ above the canopy (Table 2). Among all observed VOCs, isoprene presented the largest amplitude between day- and night-time concentrations, this behaviour being typical of those biogenic compounds whose emissions are light and temperature dependent (Guenther et al., 1993; Goldstein et al., 1998). Night-time isoprene concentrations were close to our detection limit and started to increase steadily early in the morning, around $6.30 \mathrm{a} . \mathrm{m}$. in response to the temperature and PAR increase. Maximum concentrations occurred in the afternoon, peaking between $2.0-5.0 \mathrm{ppbv}$ and $2.0-16.9 \mathrm{ppbv}$ at 10 and $2 \mathrm{~m}$ heights, respectively. In comparison, maximum atmospheric mixing ratios of about $10 \mathrm{ppbv}$ were found during June above a $Q$. pubescens forest near Marseille (France) by Simon et al. (2005). A decrease in isoprene concentration was observed in the evening, as a consequence of isoprene emission dropping and the simultaneous consumption by $\mathrm{OH}$ radicals and diffusion. Isoprene mixing ratios continued to drop gradually during night-time and reached their minimum in the early morning.

The amplitude of the isoprene air concentration diurnal cycle varied strongly from day-to-day in response to environmental condition changes. By combining all the daytime isoprene data above the canopy, a stronger correlation was found with ambient temperature than with PAR. This relationship between daytime isoprene mixing ratios and temperature (at $10 \mathrm{~m}$ a.g.l.) was found to be exponential and the $\log$ linear fit of isoprene against temperature $\left({ }^{\circ} \mathrm{C}\right)$ gave a relationship of $e^{0.1334 T}$ with a coefficient of determination, $R^{2}$, of 0.79 . An exponential relationship was also found between isoprene mixing ratios and temperature measured at $2 \mathrm{~m}$ a.g.1 (Fig. 4).

Throughout the measurement period a clear gradient in the vertical profile of isoprene concentrations was observable, with an average of $40 \%$ higher concentrations at $2 \mathrm{~m}$ than at $10 \mathrm{~m}$ a.g.l.

Isoprene fluxes measured during the campaign are shown in Fig. 5, along with PAR and $u_{*}$ measured simultaneously at $10 \mathrm{~m}$. Between 10:00 and 17:00 local time, PAR ranged between 200 and $2015 \mu \mathrm{mol} \mathrm{m}^{-2} \mathrm{~s}^{-1}$ with an average of $1500 \mu \mathrm{mol}$ quanta $\mathrm{m}^{-2} \mathrm{~s}^{-1}$. Among the measured compounds, isoprene showed by far the largest flux values with an average daytime emission of $2.77 \mathrm{mg} \mathrm{m}^{-2} \mathrm{~h}^{-1}$. Significant positive isoprene fluxes were only observed during daytime, following diel cycles with mid-day maxima ranging from 2.0 to $9.7 \mathrm{mg} \mathrm{m}^{-2} \mathrm{~h}^{-1}$. Isoprene fluxes reached zero after sunset or were rejected due to stratified conditions $\left(u_{*}<0.15 \mathrm{~m} \mathrm{~s}^{-1}\right)$. 

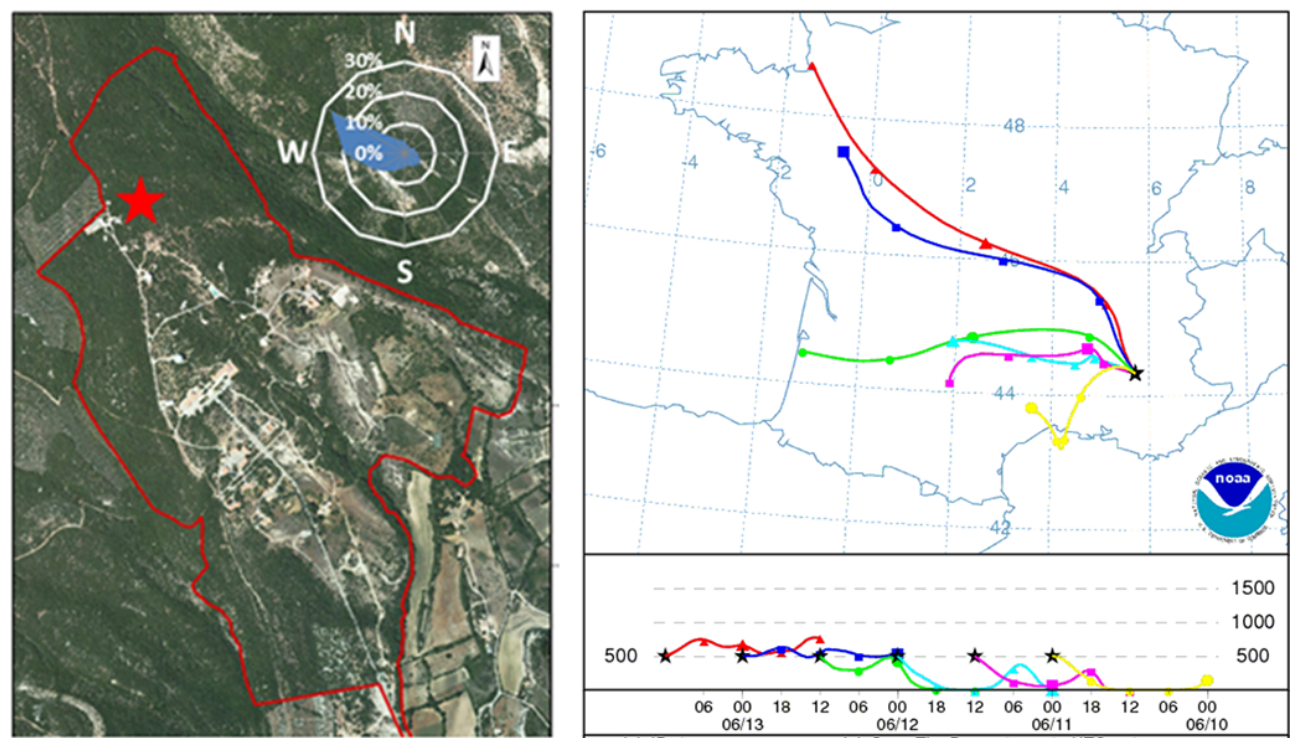

Figure 2. (left) Satellite photo of the Observatoire of Haute Provence. The red star represents the location of the measurements. Wind rose: wind direction origins (\%) from 4 until 17 June 2012. (right) Location of the $\mathrm{O}_{3} \mathrm{HP}$ in the southeast of France. $24 \mathrm{~h}$ duration backward trajectories ending at 00:00 UTC 13 June 2012 (NOAA HYSPLIT MODEL).

Table 2. Statistical summary of volume mixing ratios (ppbv) and fluxes of 12 targeted VOC above the canopy (10 m) of the Oak Observatory of the Observatoire de Haute Provence.

\begin{tabular}{|c|c|c|c|c|c|c|}
\hline \multirow[t]{2}{*}{$m / z$} & \multirow[t]{2}{*}{ Identified compound } & \multicolumn{3}{|c|}{ Volume mixing ratios [ppbv] } & \multirow{2}{*}{$\begin{array}{c}\text { Mean flux }\left[\mathrm{mg} \mathrm{m}^{-2} \mathrm{~h}^{-1}\right] \\
\text { Mean } \\
(10: 00-17: 00)\end{array}$} & \multirow{2}{*}{$\begin{array}{c}\text { Flux }\left[\mathrm{mg} \mathrm{m}^{-2} \mathrm{~h}^{-1}\right] \\
\text { Daily } \max \end{array}$} \\
\hline & & $\begin{array}{c}\text { Mean } \\
\text { 24h statistics }\end{array}$ & $\begin{array}{c}\text { Mean } \\
(10: 00-17: 00)\end{array}$ & Daily max & & \\
\hline 33 & Methanol & 2.28 & 2.48 & $1.48-5.35$ & 0.31 & $0.20-0.63$ \\
\hline 45 & Acetaldehyde & 0.38 & 0.42 & $0.20-1.39$ & & \\
\hline 59 & Acetone & 1.28 & 1.35 & $0.88-2.45$ & & \\
\hline 69 & Isoprene & 1.19 & 2.09 & $1.70-4.97$ & 2.77 & $2.0-9.7$ \\
\hline 71 & $\mathrm{MVK}+\mathrm{MACR}$ & 0.21 & 0.28 & $0.11-0.75$ & 0.03 & 0.10 \\
\hline $79^{*}$ & Benzene & 0.07 & 0.08 & $0.11-0.75$ & & \\
\hline $93^{*}$ & Toluene & 0.05 & 0.09 & $0.13-1.37$ & & \\
\hline 137 & Monoterpenes & 0.06 & 0.06 & $0.06-0.25$ & & \\
\hline
\end{tabular}

* Derived from 5 min hourly mass scans.

\subsubsection{MVK + MACR mixing ratios and above canopy fluxes}

The sum of MVK and MACR (signal at $m / z$ 71) had an average mixing ratio of 0.2 ppbv. Most of the days, MVK+MACR displayed a diurnal variability with daytime maxima ranging between 0.1 and $0.8 \mathrm{ppbv}$ and night-time minima in the order of 20-40 pptv (Fig. 6). On the 6, 15 and 16 June, MVK+MACR did not exhibit the same diurnal trend as usually observed and its night-time concentration remained unusually high at $0.2-0.3 \mathrm{ppbv}$. These three nights (from 5-6, 14-15 and 15-16 June) were characterized by low winds and thermally stratified conditions: indeed, the temperature profiles inside the forest canopy exhibited a clear vertical gradient (of $4{ }^{\circ} \mathrm{C}$ in $5 \mathrm{~m}$ ) with cooler temperatures close to the forest floor. MVK+MACR high concentrations can therefore be explained by weak vertical exchanges leading to their accumulation within and just above the canopy. This suggests that night-time removal was less efficient than the high deposition rates that have recently been reported for MVK/MACR (Karl et al., 2010; Misztal et al., 2011).

The present study showed a strong correlation $\left(R^{2}=0.84\right.$, slope $=0.12)$ between MVK+MACR and isoprene during daytime hours ( 7 a.m. to 7 p.m), supporting that isoprene oxidation was responsible for the formation of the first-order oxidation products MVK and MACR. A delay of about $2 \mathrm{~h}$ in the morning rise of concentrations was observed and likely represents the time that isoprene needed to be degraded.

Fluxes of MVK+MACR showed a general trend of emission with diurnal cycles but are subject to considerable 


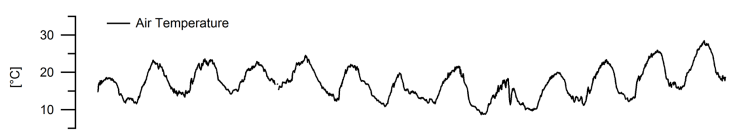
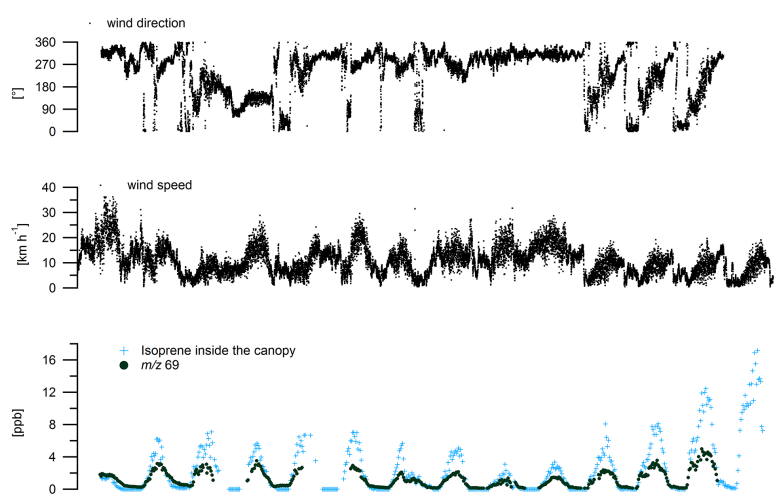

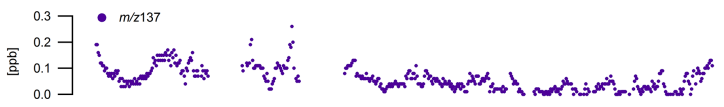
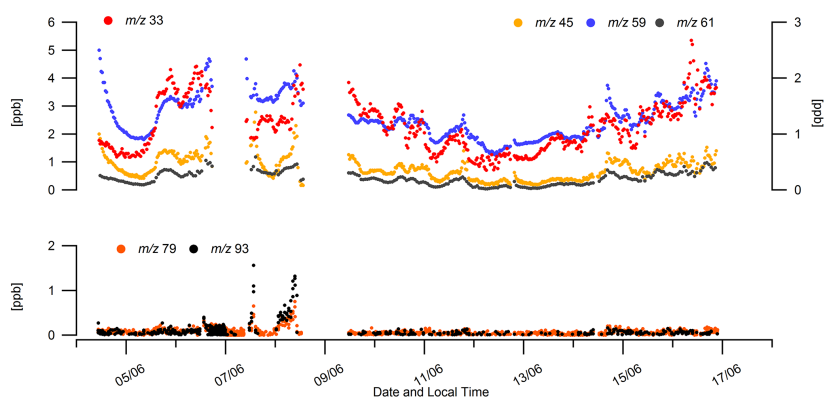

Figure 3. Time series of VOCs and meteorological parameters recorded from 4 to 16 June. Benzene $(\mathrm{m} / \mathrm{z} 79)$, toluene $(\mathrm{m} / \mathrm{z} 93)$, methanol $(\mathrm{m} / \mathrm{z} 33)$, acetaldehyde $(\mathrm{m} / \mathrm{z} 45)$, acetone $(\mathrm{m} / \mathrm{z} 59)$, sum of acetic acid and glycolaldehyde $(\mathrm{m} / z, 61)$, total monoterpenes $(m / z$ 137) and isoprene $(m / z 69)$ were measured by PTR-MS above the canopy along with temperature and wind direction. Isoprene inside the canopy ( $2 \mathrm{~m}$ a.g.l) was measured by online GC-FID from 4 to 17 June.

Table 3. Quality assessment of isoprene, methanol and MVK+MACR fluxes.

\begin{tabular}{lrrr}
\hline & Isoprene & Methanol & MVK+MACR \\
\hline $\begin{array}{l}\text { Failure percentage among flux data points } \\
\text { Quality tests: }\end{array}$ & & \\
\hline$u^{*}<0.15 \mathrm{~m} \mathrm{~s}^{-1}$ & $18 \%$ & $19 \%$ & $20 \%$ \\
$F<$ LOD & $11 \%$ & $10 \%$ & $37 \%$ \\
$\Delta s$ textgreater 60\% & $1 \%$ & $0 \%$ & $3 \%$ \\
\hline Data that passed the quality assessment: & & \\
\hline $\begin{array}{l}\text { High-quality stationary data } \\
\Delta s<30 \%\end{array}$ & $94 \%$ & $93 \%$ & $81 \%$ \\
$\begin{array}{l}\text { Low-quality stationary data } \\
30 \%<\Delta s<60 \%\end{array}$ & $6 \%$ & $7 \%$ & $19 \%$ \\
\hline
\end{tabular}

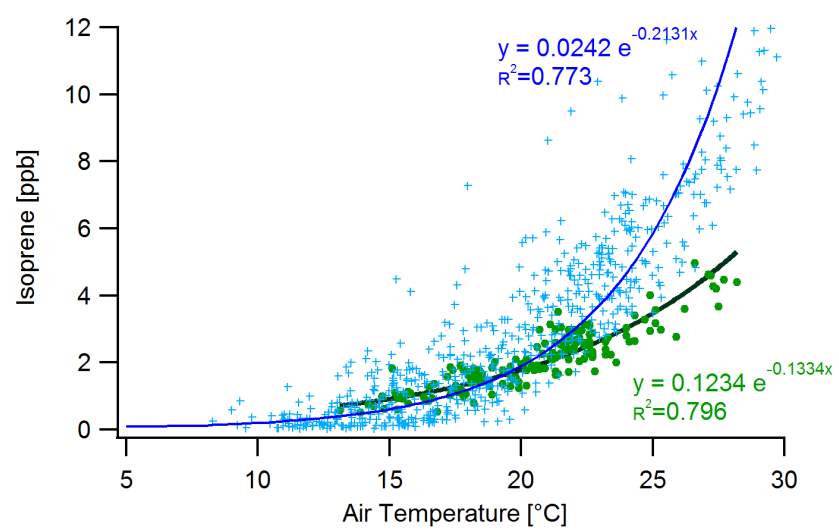

Figure 4. Relationship between daytime isoprene mixing ratios (ppbv) and air temperature $\left({ }^{\circ} \mathrm{C}\right)$. Data points and fit lines in green and blue correspond to measurements at 10 and $2 \mathrm{~m}$ height respectively.
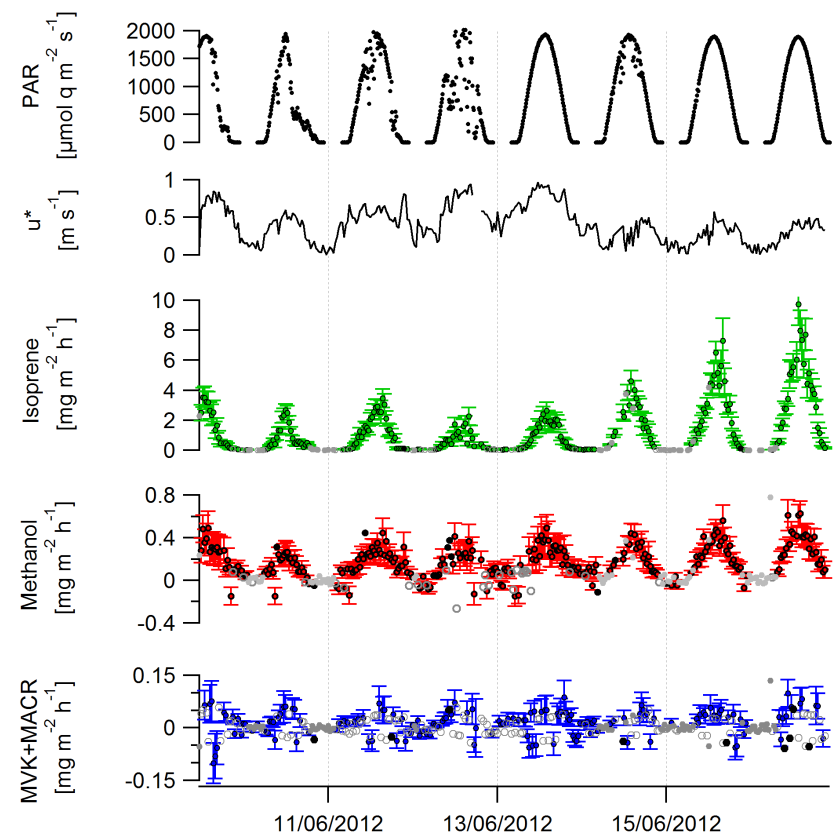

$$
\begin{array}{cccc|}
\hline & \bullet & \text { Passed all the tests } \\
\mathrm{u}^{*}<0.15 \mathrm{~m} \mathrm{~s}^{-1} \circ & <\text { LOD } \bullet & \text { Non Stationary }
\end{array}
$$

Figure 5. Time series of MVK+MACR, methanol and isoprene fluxes along with friction velocity and PAR measured above the canopy from 4 June to 16 June. Flux error bars show \pm standard deviation of the covariance for $t_{\text {lag }}$ far away from the true lag $(+150,-180 \mathrm{~s})$. 


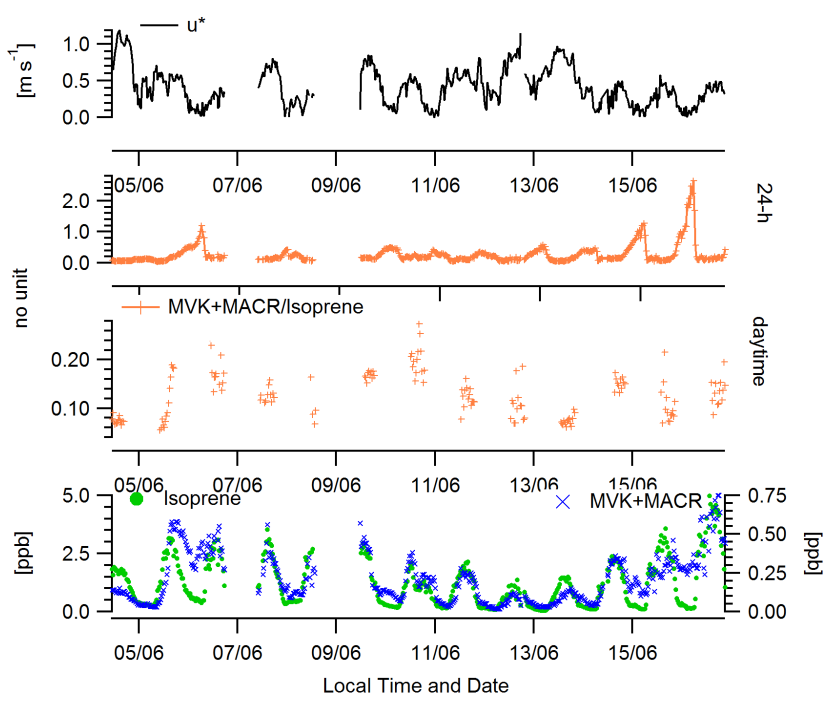

Figure 6. Time series of MVK+MACR and isoprene concentrations, $[\mathrm{MVK}+\mathrm{MACR}] /$ isoprene ratio (daytime data set and whole data set) along with friction velocity above the canopy of the $\mathrm{O}_{3} \mathrm{HP}$.

uncertainties (Fig. 5). Indeed as MVK+MACR fluxes were small the covariance function was noisy and the true peak in the covariance function was not easily identified and consequently half of the fluxes were below the detection limit (Table 3). Considering only positive values, fluxes never exceeded $0.10 \mathrm{mg} \mathrm{m}^{-2} \mathrm{~h}^{-1}$ and exhibited a mean value around $0.03 \mathrm{mg} \mathrm{m}^{-2} \mathrm{~h}^{-1}$, which equates to $3 \%$ of the isoprene flux averaged over the same data points. Overall, MVK+MACR fluxes were weak and no reliable evidence of deposition was found.

\subsubsection{Monoterpene mixing ratios}

Due to the inability of the PTR-MS to distinguish isomer molecules, only the sum of all monoterpenes was measured. Overall, the vegetation at the $\mathrm{O}_{3} \mathrm{HP}$ was a weak monoterpene emitter. Ambient concentrations derived from $\mathrm{m} / z 137$ were low, with an average value of $0.06 \mathrm{ppbv}$ and a maximum at $0.25 \mathrm{ppbv}$ over the whole measurement period (Fig. 3). Whereas diurnal branch-level emission rates of monoterpenes were observed for oaks and maple trees (GenardZielinksi et al., 2014), ambient concentrations at the canopy level did not exhibit a clear diurnal variability. At nights, especially when the turbulence was low, a build-up of monoterpenes was observed. Night-time concentrations were probably affected by remaining monoterpenes, emitted on the day before, and that have not been entirely consumed by daytime oxidants. Observed nocturnal maximum may also be attributed to nocturnal emissions from monoterpenes storing plants from the understorey vegetation. This nocturnal maximum is emphasized by the shallow nocturnal boundary layer, and the low concentrations of oxidizing species, leading to higher monoterpene concentrations.

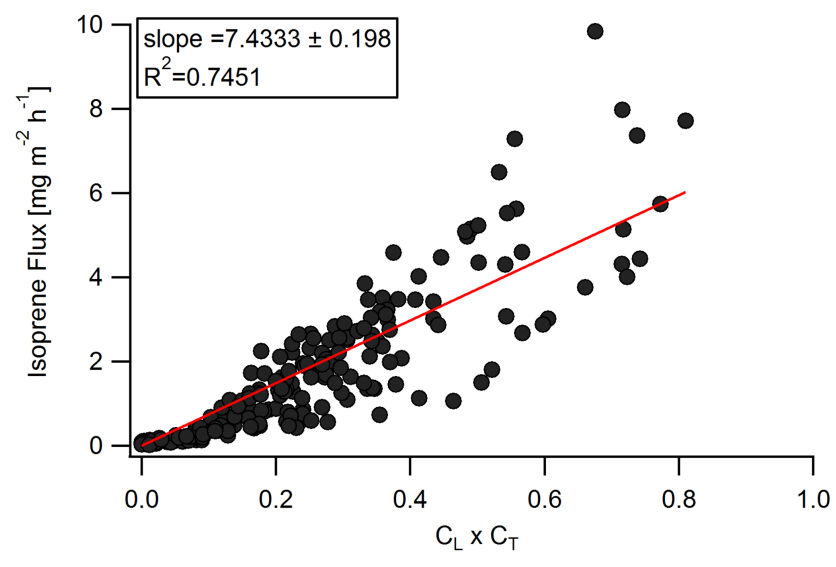

Figure 7. (Right) Isoprene fluxes against the combined temperature and light scaling factors $\left(C_{\mathrm{L}}\right.$, $\left.C_{\mathrm{T}}\right): \quad C_{\mathrm{T}}=e^{\frac{C_{T 1}\left(T-T_{\mathrm{S}}\right)}{\mathrm{RTT}_{\mathrm{S}}}} / e^{\frac{C_{T 1}\left(T-T_{S}\right)}{\mathrm{RTT}_{\mathrm{S}}}} / 1+e^{\frac{C_{T 2}\left(T-T_{\mathrm{M}}\right)}{\mathrm{RTT}_{\mathrm{S}}}}, \quad$ and $C_{\mathrm{L}}=\alpha C_{\mathrm{L} 1} L / \sqrt{\left(1+a^{2} L^{2}\right)} \quad$ with $\quad \mathrm{L}=$ Photosynthetically Active Radiation (PAR) in $\mu \mathrm{mol}\left(\right.$ photon) $\mathrm{m}^{-2} \mathrm{~s}^{-1}$, $a=0.0027 \mathrm{~m}^{2} \mathrm{~s} \mathrm{\mu mol}^{-1}, \quad C_{\mathrm{L} 1}=1.066 \quad$ units, $C_{T 1}=95000 \mathrm{~J} \mathrm{~mol}^{-1}, \quad C_{T 2}=230000 \mathrm{~J} \mathrm{~mol}^{-1}, \quad T_{\mathrm{S}}=$ standard temperature in Kelvin $\left(303 \mathrm{~K}\right.$ to $\left.30^{\circ} \mathrm{C}\right), T_{\mathrm{M}}=314 \mathrm{~K}$.

Concentrations of monoterpenes might also be affected by advection of emissions from surrounding vegetation such as lavender or garrigue plants which are known to be monoterpene emitters (Owen et al., 2001; Boeckelmann, 2008).

\subsubsection{Oxygenated VOC mixing ratios and fluxes}

At the $\mathrm{O}_{3} \mathrm{HP}$, several $\mathrm{O}_{\mathrm{x}} \mathrm{VOCs}$ were detected. Due to their relatively long lifetimes (see Table 1) and widespread sources, $\mathrm{O}_{\mathrm{x}}$ VOCs showed elevated concentrations and less pronounced diurnal cycles than isoprene. Methanol was the most abundant VOC accounting for $\sim 40 \%$ of the total measured VOC concentrations. Methanol mixing ratios at $\mathrm{O}_{3} \mathrm{HP}$ ranged between 0.7 to $5.5 \mathrm{ppbv}$ (Fig. 3). Methanol's relatively long atmospheric lifetime of $\sim 10$ days (Atkinson et al., 1999) resulted in elevated background concentrations $(>0.7 \mathrm{ppbv})$. However, it was the only $\mathrm{O}_{\mathrm{x}} \mathrm{VOC}$ with a detectable net emission flux suggesting that local biogenic emissions also influence the observed concentrations. Methanol fluxes exhibited diurnal cycles with emission fluxes starting at sunrise, increasing during daytime as temperature and PAR increased, and stopping after sunset. Daily maximum methanol fluxes ranged between 0.20 and $0.63 \mathrm{mg} \mathrm{m}^{-2} \mathrm{~h}^{-1}$, i.e. about 5 to 20 times lower than the isoprene fluxes. Previous studies have shown both positive and negative fluxes of methanol. In comparison, a net emission (up to $0.5 \mathrm{mg} \mathrm{m}^{-2} \mathrm{~h}^{-1}$ ) with few transient deposition events has been reported for a tropical rainforest in Costa Rica (Karl et al., 2004), whereas a net deposition for methanol has been reported in a Southeast Asian rainforest (Langford et al., 2010; Misztal et al., 2011). Our findings at the $\mathrm{O}_{3} \mathrm{HP}$ 
indicated that the net exchange in methanol was positive. As above-canopy fluxes reflect the sum of production and removal processes, this does not mean that there was no bidirectional exchange, but that the component fluxes showing emission always overwhelmed the deposition components.

Among the other $\mathrm{O}_{\mathrm{x}}$ VOCs detected were acetaldehyde $(m / z 45)$, acetone $(m / z 59)$ but also three compounds with a $m / z$ ratio of 61,73 and 75 , derived from the hourly 5 min scan. After methanol, acetone was the most abundant $\mathrm{O}_{\mathrm{x}} \mathrm{VOC}$ with atmospheric mixing ratios ranging between 0.6 and 2.5 ppbv. Acetaldehyde followed with slightly lower concentrations around $0.2-1.2 \mathrm{ppbv}$. It is striking that all of these mentioned $\mathrm{O}_{\mathrm{x}}$ VOCs had a good covariance (Fig. 3) and most of them correlated well with each other. The strongest correlations were between $\mathrm{m} / z 45$ and $\mathrm{m} / z 59\left(R^{2}=0.7\right.$, slope $=0.78), m / z \quad 75$ and $m / z 61 \quad\left(R^{2}=0.70\right) m / z \quad 59$ and $m / z 61\left(R^{2}=0.75\right.$, slope $\left.=1.2\right)$ but also $m / z 59$ and $m / z 73\left(R^{2}=0.65\right)$. Correlations with methanol were lower $\left(R^{2}<0.5\right)$, likely due to its relatively strong biogenic source and also its high background. These significant correlations between every $\mathrm{O}_{\mathrm{x}}$ VOCs could be the result of the boundary layer dynamics, but still suggest that they had a common source or that their formation mechanisms responded to environmental factors in a similar manner. For example, the good correlation between $\mathrm{m} / \mathrm{z} 75$ and $\mathrm{m} / \mathrm{z} 61$ suggests that these masses include important contributions from hydroxyacetone and glycolaldehyde, two second-generation products from isoprene. However, additional contributions from other compounds cannot be excluded.

From 5 to 7 June, changes in the wind direction were observed with air masses coming from the south and through the region of Marseille and Manosque. This southern wind shift was concurrent with the simultaneous increase of methanol, acetone, acetic acid and acetaldehyde. Respectively, from 10 to 14 June, when the site was under the influence of northern winds, $\mathrm{O}_{\mathrm{x}}$ VOCs were at their background levels. As $\mathrm{O}_{\mathrm{x}}$ VOCs have a relatively high lifetime of about a week, long-distance transport seems to influence their ambient concentrations at the $\mathrm{O}_{3} \mathrm{HP}$. On the other hand, the progressive and simultaneous increase of concentrations for all these $\mathrm{O}_{\mathrm{x}}$ VOCs during the last days of the field campaign (i.e. 14-17 June) was remarkable, and was characterized by a steady rise in the ambient concentrations and solar radiation. This simultaneous increase of $\mathrm{O}_{\mathrm{x}} \mathrm{VOC}$ concentration with temperature and PAR likely reflects an additional biogenic source. Evidence of primary emission of $\mathrm{O}_{\mathrm{x}} \mathrm{VOCs}$ has been reported for branch-level measurements from $Q$. pubescens individuals at the $\mathrm{O}_{3} \mathrm{HP}$ (Genard-Zielinksi et al., 2014). As background levels of acetone and acetaldehyde were high and emission rates at the branch-level were very low (mean: 0.21 and $0.09 \mu \mathrm{g} \mathrm{Cg}_{\text {dry weight of biomass }}^{-1} \mathrm{~h}^{-1}$ respectively), no significant fluxes were measured above the canopy by the DEC method.

\section{Discussion on isoprene fluxes and in-canopy oxidation}

\subsection{Isoprene standardized flux and biomass emission factor}

Isoprene fluxes presented in Sect. 3.2.1 confirm that emissions at the $\mathrm{O}_{3} \mathrm{HP}$ are dominated by large isoprene fluxes. During the CANOPEE field campaign, the daily maxima of the isoprene fluxes ranged between 2.0 to $9.7 \mathrm{mg} \mathrm{m}^{-2} \mathrm{~h}^{-1}$ with a mean daytime flux of $2.0 \mathrm{mg} \mathrm{m}^{-2} \mathrm{~h}^{-1}$. This is in fairly good agreement with Baghi et al. (2012) who reported isoprene fluxes with values in the range $5.4-10 \mathrm{mg} \mathrm{m}^{-2} \mathrm{~h}^{-1}$ around midday, measured by DEC during a 2-day period in early August 2010 at the same site.

To our knowledge, above-canopy isoprene fluxes recorded at the $\mathrm{O}_{3} \mathrm{HP}$ are the largest reported in the Mediterranean basin. Most of the VOC studies in this region were about monoterpene emitters. In western Italy, above a low macchia ecosystem, Davison et al. (2009) reported relatively small isoprene fluxes with mean daytime values of $0.097,0.016$ and $0.032 \mathrm{mg} \mathrm{m}^{-2} \mathrm{~h}^{-1}$ measured using the DEC method with three different PTR-MS. Furthermore, no significant isoprene fluxes were found above a pine-oak forest site in Italy and above orange plantations in Spain during the BEMA's field studies (Velentini et al., 1997; Darmais et al., 2000). As the number of isoprene flux measurements at the canopy level in the Mediterranean region is limited, we extend our comparison to other ecosystems in the world. A non-exhaustive overview of isoprene flux measurements in Mediterranean, tropical, and temperate ecosystems is presented in Table 4. Reported values are displayed as found in the reference papers and demonstrate a difficulty of intercomparison due to the multiple statistical ways of expressing the results (mean, median, range) used in every study. However, this table gives an idea of the orders of magnitude of isoprene emission rates at the canopy scale, and confirms that isoprene emissions from Mediterranean forests can be similar to or higher than those observed in other regions of the world which are dominated by isoprene-emitting vegetation. For instance, maximum isoprene fluxes of 6.1, 7.1, and $10.8 \mathrm{mg} \mathrm{m}^{-2} \mathrm{~h}^{-1}$ were observed respectively above a mature lowland in the central Amazon (Kuhn et al., 2007), a coniferous forest in eastern Belgium (Laffineur et al., 2011) or a deciduous forest in Germany (Spirig et al., 2005) and are very close to the maxima recorded at the $\mathrm{O}_{3} \mathrm{HP}$. Considerably higher isoprene fluxes reaching up to $30 \mathrm{mg} \mathrm{m}^{-2} \mathrm{~h}^{-1}$ were reported only from an oil palm plantation in Malaysia (Misztal et al., 2011).

Isoprene fluxes at the $\mathrm{O}_{3} \mathrm{HP}$ were also normalized to standard conditions (temperature and PAR at the canopy level of $30{ }^{\circ} \mathrm{C}$ and $1000 \mu \mathrm{mol} \mathrm{m}^{-2} \mathrm{~s}^{-1}$ respectively) using the G93 algorithm (Guenther et al., 1993). By plotting all measured fluxes against the combined temperature and light scaling factors $\left(C_{\mathrm{L}}, C_{\mathrm{T}}\right)$, a standardized flux $F_{\text {standard }}$ (or basal 
Table 4. Non-exhaustive overview of above-canopy isoprene fluxes and volume.

\begin{tabular}{|c|c|c|c|c|c|c|c|}
\hline \multirow[t]{2}{*}{ Site } & \multirow[t]{2}{*}{ Method } & \multicolumn{3}{|c|}{ Daytime fluxes $\left[\mathrm{mg} \mathrm{m}^{-2} \mathrm{~h}^{-1}\right]$} & \multirow{2}{*}{$\begin{array}{r}\text { Daytime VMR [ppbv] } \\
\text { Mean/(Median) } \\
\text { (max.) }\end{array}$} & \multirow[t]{2}{*}{ Season } & \multirow[t]{2}{*}{ Reference } \\
\hline & & Mean (Median) & SD conditions ${ }^{1}$ & $\operatorname{Max}$ & & & \\
\hline \multicolumn{8}{|l|}{ Mediterranean } \\
\hline $\begin{array}{l}\text { Haute Provence, France } \\
\text { downy oaks }\end{array}$ & $\mathrm{DEC}$ & $2.77(2.39)$ & 7.4 & 9.85 & $\begin{array}{r}2.09(2.10) \\
(\max . \sim 4.97)\end{array}$ & Spring 2013 & This study \\
\hline $\begin{array}{l}\text { Haute-Provence, France } \\
\text { downy oaks }\end{array}$ & $\mathrm{DEC}$ & $\begin{array}{l}- \\
-\end{array}$ & & 10.08 & - & Summer 2010 & Baghi et al. (2012) \\
\hline $\begin{array}{l}\text { Western Italy, } \\
\text { macchia ecosystem }\end{array}$ & $\mathrm{DEC}$ & $(0.10 / 0.16 / 0.32)^{2}$ & 0.43 & 0.29 & $\begin{array}{l}(0.16 / 0.25 / 0.17)^{2} \\
\quad(\max . \sim 0.60)\end{array}$ & Spring 2007 & Davison et al. (2009b) \\
\hline \multicolumn{8}{|l|}{ Tropical } \\
\hline $\begin{array}{l}\text { Malaysia Borneo } \\
\text { oil plantation }\end{array}$ & $\mathrm{DEC}$ & $9.71(8.45)$ & 7.80 & 28.94 & $\begin{array}{r}13.10(13.80) \\
(\max .21 .40)\end{array}$ & Spring 2008 & Misztal et al. (2011) \\
\hline $\begin{array}{l}\text { Malaysia } \\
\text { rainforest }\end{array}$ & $\mathrm{DEC}$ & $0.93(0.46)$ & 1.60 & 3.7 & $\begin{array}{r}1.30(1.00) \\
(\max .3 .40)\end{array}$ & Spring-summer 2008 & Langford et al. (2010) \\
\hline $\begin{array}{l}\text { Central Amazon } \\
\text { mature lowland }\end{array}$ & REA & $2.38 \pm 1.8$ & & 6.12 & $\begin{array}{r}3.40 \pm 1.8(3.2) \\
(\max .6 .60)\end{array}$ & Summer 2001 & Kuhn et al. (2007) \\
\hline $\begin{array}{l}\text { La Selva, Costa Rica } \\
\text { oil tree }\end{array}$ & DEC & 1.35 & 1.72 & 2,90 & $\begin{array}{r}1.66 \\
(\max . \sim 3.00)\end{array}$ & Spring 2003 & Karl et al. (2004) \\
\hline $\begin{array}{l}\text { Tabajos, Brazil } \\
\text { terra firme }\end{array}$ & $\mathrm{EC}$ & - & 2.40 & 2.00 & $(\max . \sim 4.00)$ & Spring 2000 & Rinne et al. (2002) \\
\hline \multicolumn{8}{|l|}{ Temperate } \\
\hline $\begin{array}{l}\text { Central Massachusetts, } \\
\text { mixed canopy }\end{array}$ & $\mathrm{DEC}$ & 4.40 & $3.70-17.20$ & $\sim 13.50$ & $(\max .>10.00)$ & Spring 2007 & McKinney et al. (2011) \\
\hline $\begin{array}{l}\text { Germany } \\
\text { mixed deciduous: beech, oak }\end{array}$ & $\mathrm{DEC}$ & 3.38 & 2.88 & 10.8 & $(\max \sim 4.00)$ & Summer 2003 & Spirig et al. (2005) \\
\hline $\begin{array}{l}\text { Eastern Belgium } \\
\text { mixed coniferous species }\end{array}$ & $\mathrm{DEC}$ & - & $2.01-3.28$ & 7.06 & $(\max .<1.50)$ & Summer 2009 & Laffineur et al. (2011) \\
\hline
\end{tabular}

emission rate) of $7.4 \mathrm{mg} \mathrm{m}^{-2} \mathrm{~h}^{-1}$ was derived from the fit line with zero intercept (Fig. 7).

For comparison, enclosure measurements for seven different branches of $Q$. pubescens at the $\mathrm{O}_{3} \mathrm{HP}$ during CANOPEE resulted in emission factors $\mathrm{EF}_{\text {biomass }}$ ranging between 30 and $140 \mu \mathrm{g} \mathrm{g}_{\text {dry weight of biomass }}^{-1} \mathrm{~h}^{-1}$ (hereafter, $\mu \mathrm{g} \mathrm{g}_{\text {dwt }}^{-1} \mathrm{~h}^{-1}$ ) with a median value of $70 \pm 8 \mu \mathrm{g} \mathrm{g}_{\text {dwt }}^{-1} \mathrm{~h}^{-1}$ (Genard-Zielinksi et al., 2014). The average $\mathrm{EF}_{\text {biomass }}$ was then upscaled to give an standardized flux $F_{\text {standard: }}$

$F_{\text {standard-upscaled }}=\mathrm{EF}_{\text {biomass }} \times \sum_{h=0}^{h_{\mathrm{c}}} \mathrm{LAI}(h) \cdot \operatorname{LMA}(h)$,

where $h$ is the distance above ground (unit: $\mathrm{m}$ ), $h_{\mathrm{c}}$ the canopy height, LAI the mean leaf area index (unit: $\mathrm{m}^{-2} \mathrm{~m}^{-2}$ ) and LMA the leaf dry mass per unit area (unit: $\mathrm{g} \mathrm{m}^{-2}$ ). The resulting up-scaled basal emission rate $F_{\text {standard-upscaled was }}$ $18 \pm 5 \mathrm{mg} \mathrm{m}^{-2} \mathrm{~h}^{-1}$. Fluxes estimated by extrapolating leaflevel measurements were twofold higher than the average figure derived from DEC measurements. We consider this to be a reasonably good agreement since a factor of 2 of difference can be expected when comparing techniques over different spatial scales, due to uncertainties in the extrapolation, in addition to the uncertainties of both measurements. A reason for the difference certainly arises also from the normalization of DEC fluxes to standard conditions using the air tem- perature and PAR above the canopy. Since a significant fraction of the canopy experiences lower light levels, the standardized emission flux using an above-canopy PAR is underestimated. For example, a normalization using an in-canopy PAR would lead to an $F_{\text {standard }}$ increase of about $100 \%$. On the other hand, the normalization using actual leaf temperature, which is usually a couple of degrees higher than ambient temperature, would lead to lower $F_{\text {standard }}$ values. A canopy structure model would be required to better quantify both effects. Additional uncertainty comes from the difference in biomass emission factors $\mathrm{EF}_{\text {biomass }}$, which, can vary by more than a factor of 4 between tree individuals, as indicated by the branch-level measurements (Genard-Zielinksi et al., 2014). Leaf level measurements are often performed on sun foliage, which has larger emission rates as compared to the whole crown. Further, an overestimation of basal emission rates based on leaf level emissions could be the chemical loss of isoprene within the canopy, which we tentatively examine hereafter.

\subsection{Isoprene oxidation within the canopy}

In recent years, much attention has been devoted to understanding isoprene chemistry, particularly in sites such as the $\mathrm{O}_{3} \mathrm{HP}$, where the isoprene emissions are strong and the $\mathrm{NO}_{\mathrm{x}}$ levels are low (NO mean value $\sim 25 \mathrm{ppt}$ ). Inconsistencies between observations in rural sites and model estimates of 
the ratio of isoprene to its oxidation products have pointed out uncertainties associated with the understanding of the mechanism of isoprene oxidation. Lately, laboratory studies have elaborated rate coefficients and product branching ratio yields (Paulot et al., 2009; Peeters et al., 2009; da Silva et al., 2009; Peeters and Müller, 2010; Fuchs et al., 2013). In the following section, we investigate the isoprene oxidation and production of MVK and MACR at the $\mathrm{O}_{3} \mathrm{HP}$ and discuss our results with regard to recent findings that suggest very low production yields of MVK and MACR under low $\mathrm{NO}_{\mathrm{x}}$ conditions (NO < 70 ppt) (Liu et al., 2013).

$\mathrm{OH}$-oxidation of isoprene is initiated by the addition of the hydroxy radical to the double bonds of isoprene. The alkyl radical formed reacts with oxygen $\left(\mathrm{O}_{2}\right)$ to form alkyl peroxyl radicals $\left(\mathrm{HOC} \mathrm{H} 8 \mathrm{OO}^{\circ}\right.$ ), commonly called ISOPOO. ISOPOO radicals subsequently react either with NO (Tuazon and Atkinson, 1990), hydroperoxyl radicals $\mathrm{HO}_{2}$ (Paulot et al., 2009), or organic peroxyl radicals $\mathrm{RO}_{2}$ (Jenkin et al., 1998). Additional isomerization reactions of ISOPOO radicals have also been suggested in the recent literature (Peeters et al., 2009; da Silva et al., 2010; Fuchs et al., 2013). At high $\mathrm{NO}_{\mathrm{x}}$ concentrations the dominant fate of ISOPOO is generally the reaction with $\mathrm{NO}$. However, under low $\mathrm{NO}_{\mathrm{x}}$ conditions, reaction with $\mathrm{HO}_{2}$ dominates and leads to lower MVK and MACR yields (Miyoshi et al., 1994; Ruppert and Becker, 2000). Using atmospheric simulation chambers, Liu et al. (2013) found the lowest MVK and MACR yields that have ever been reported, with values of $(3.8 \pm 1.3) \%$ for MVK and $(2.5 \pm 0.9) \%$ for MACR, i.e. more than $60 \%$ less than in previous "low-NO ${ }_{\mathrm{x}}$ " studies (Miyoshi et al., 1994; Ruppert and Becker, 2000; Navarro et al., 2011), and about 10 times lower than via the NO pathway.

At the $\mathrm{O}_{3} \mathrm{HP}$, the 12 days of measurements featured a [MVK+MACR]-to-isoprene ratio of $0.13 \pm 0.05$ during daytime (Fig. 8). It has to be considered that this ratio could be lower if any interference occurred at $m / z 71$ from other oxidation products. Despite this possible overestimation, the [MVK+MACR]-to-isoprene ratio at the $\mathrm{O}_{3} \mathrm{HP}$ is at the lower end of the range that has previously been observed in other ecosystems of the world. This ratio usually falls to around 0.3-0.75, and is dependent on the sampling height (Montzka et al., 1993; Biesenthal et al., 1998; Holzinger et al., 2002). Nevertheless, a few studies have shown ratios close to our estimates: a ratio of 0.12 has been reported in a rural forest of Michigan (Apel, 2002), and a ratio of 0.1 to 0.36 was obtained in a Southeast Asian tropical rainforest (Langford et al., 2010). The [MVK+MACR]-to-isoprene ratio reported here is in agreement with recent findings proposing weak production yields of MVK and MACR, in remote forest regions where the $\mathrm{NO}_{\mathrm{x}}$ concentrations are low.

The low [MVK+MACR]-to-isoprene ratio is also in agreement with the fluxes of mass 71 (related to MACR and MVK and possible contribution from isoprene hydroperoxides). Fluxes of mass 71 showed a general trend of emission, and thus suggest a production throughout the forest

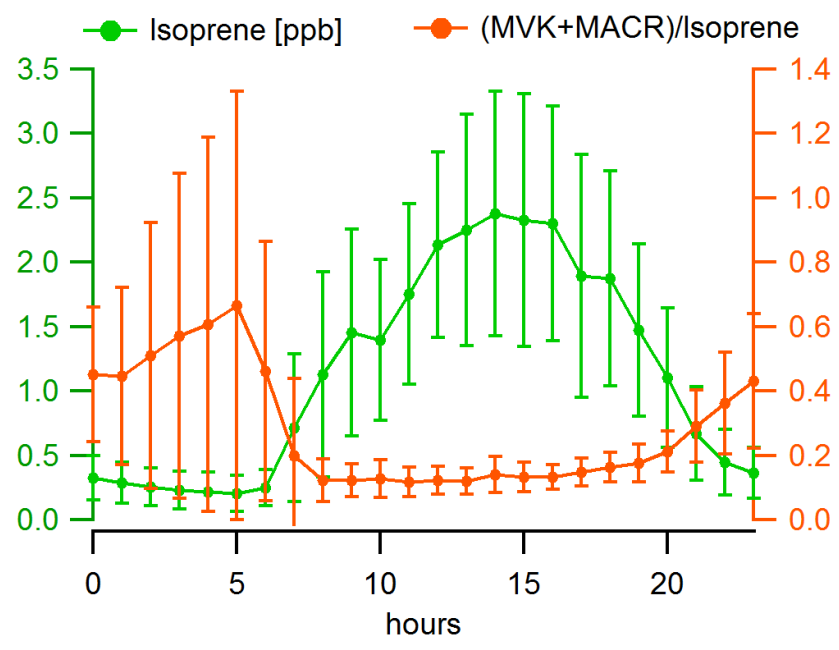

Figure 8. Averaged diel cycles of isoprene concentrations and $[\mathrm{MVK}+\mathrm{MACR}] /$ isoprene ratio measured above the canopy of the $\mathrm{O}_{3} \mathrm{HP}$ from 4 to 16 June. Vertical bars do not show error but standard deviation to the mean value.

canopy. However, the magnitude of these fluxes was very low - about $40 \%$ being below the detection limit - and the data that passed all the quality assessment tests represented about $3 \%$ of the isoprene fluxes. Estimates of the isoprene that is oxidated to MVK+MACR below the sampling height of flux measurement are usually of the order of 5 to $15 \%$, also depending on the measurement height (Stroud et al., 2005). Additionally to the low $\mathrm{NO}_{\mathrm{x}}$ conditions, which lead to low yields of MACR and MVK, minor chemical processing of isoprene is expected below the measurement height due to the canopy architecture of the $\mathrm{O}_{3} \mathrm{HP}$. The forest of the $\mathrm{O}_{3} \mathrm{HP}$ is low ( $5 \mathrm{~m}$ height on average), well ventilated and therefore closely coupled to the boundary layer above. Thus, the turbulent transport time $\tau$ between ground surface and the measurement height was estimated to be around 30-60 s in daytime (see Supplement for calculation details). This is considerably faster than the isoprene chemical degradation estimated at about $4 \mathrm{~h}$ against its oxidation by $\mathrm{OH}$ for typical summer daytime. Thus, isoprene rapidly reaches the atmosphere and does not have the time to react in a significant way with $\mathrm{OH}$ radicals from the moment of its release by the vegetation and its arrival at the sampling inlet.

\section{Conclusions}

We have presented atmospheric measurements at high resolution for concentrations and direct above-canopy fluxes of BVOCs for a Mediterranean downy oak forest.

High concentrations of isoprene have been observed, with daytime maxima ranging between $2-17$ ppbv inside the forest and 2-5 ppbv above the top of the canopy. Isoprene concentrations showed a clear diurnal cycle with a daytime maximum and a minimum in the early morning and at 
night, respectively. Above the canopy, isoprene concentrations were about $40 \%$ lower than inside the canopy; this loss was attributed to physical processes such as mixing with isoprene-depleted air masses (or, conversely, the build-up of isoprene within the canopy). Isoprene fluxes at the $\mathrm{O}_{3} \mathrm{HP}$ site were among the largest fluxes reported in the Mediterranean region, with mid-day maxima ranging between 2.0 and $9.7 \mathrm{mg} \mathrm{m}^{-2} \mathrm{~h}^{-1}$. Based on these measurements, an isoprene basal emission rate of $7.4 \mathrm{mg} \mathrm{m}^{-2} \mathrm{~h}^{-1}$ is recommended for downy oaks in this region for biogenic emission models. $\mathrm{O}_{\mathrm{x}}$ VOCs were abundant at the site with mean daytime concentration of 2.48, 1.35 and $0.42 \mathrm{ppbv}$ for methanol, acetone and acetaldehyde respectively. Of these compounds, only methanol exhibited significant fluxes, indicating a primary source inside the canopy. Methanol fluxes featured maxima daytime values ranging between 0.20 and $0.63 \mathrm{mg} \mathrm{m}^{-2} \mathrm{~h}^{-1}$, i.e. about 5 to 20 times lower than isoprene fluxes. No abovecanopy fluxes of monoterpenes have been observed, and, as a result, ambient concentrations of monoterpenes were close to the detection limits. These observations are in agreement with a branch-level study, stating that $Q$. pubescens was a strong emitter of isoprene and weak emitter of monoterpenes (Genard-Zielinksi et al., 2014).

At the forest site of the $\mathrm{O}_{3} \mathrm{HP}$, where the isoprene emissions were high and the $\mathrm{NO}_{\mathrm{x}}$ levels low, a small [MVK+MACR]-to-isoprene ratio has been observed (mean daytime value of $0.13 \pm 0.05$ ). Upward fluxes of MACR and MVK indicated a production from isoprene throughout the forest canopy, but represented less than $3 \%$ of the isoprene flux. Further, no systematic deposition fluxes could be detected for either of the investigated compounds. Therefore, we conclude that intra-canopy processes had a minor effect on above-canopy fluxes.

\section{The Supplement related to this article is available online at doi:10.5194/acp-14-10085-2014-supplement.}

Acknowledgements. We thank our colleagues for continuous support and discussion. We are grateful to the $\mathrm{O}_{3} \mathrm{HP}$ team and especially to J. P. Orts and T. Gauquelin. We thank A. Bouygues for helping with the setup. This work is supported by the French National Agency for Research (ANR 2010 JCJC 603 01). We acknowledge the INSU (ChARMEx), ADEME, CNRS and CEA for supporting funding. The $\mathrm{CEH}$ contribution to the study was supported by the FP7 project ÉCLAIRE.

Edited by: J. Rinne

\section{References}

Andreae, M. O. and Crutzen, P. J.: Atmospheric Aerosols: Biogeochemical Sources and Role in Atmospheric Chemistry, Science, 276, 1052-1058, doi:10.1126/science.276.5315.1052, 1997.

Apel, E. C.: Measurement and interpretation of isoprene fluxes and isoprene, methacrolein, and methyl vinyl ketone mixing ratios at the PROPHET site during the 1998 Intensive, J. Geophys. Res., 107, ACH 7-1-ACH 7-15, doi:10.1029/2000JD000225, 2002.

Atkinson, R., Baulch, D. L., Cox, R. A., Hampson, R. F., Kerr, J. A., Rossi, M. J., and Troe, J.: Evaluated Kinetic and Photochemical Data for Atmospheric Chemistry, Organic Species: Supplement VII, J. Phys. Chem. Ref. Data, 28, 191, doi:10.1063/1.556048, 1999.

Baghi, R., Durand, P., Jambert, C., Jarnot, C., Delon, C., Serça, D., Striebig, N., Ferlicoq, M., and Keravec, P.: A new disjunct eddy-covariance system for BVOC flux measurements - validation on $\mathrm{CO}_{2}$ and $\mathrm{H}_{2} \mathrm{O}$ fluxes, Atmos. Meas. Tech., 5, 3119-3132, doi:10.5194/amt-5-3119-2012, 2012.

Biesenthal, T. A., Bottenheim, J. W., Shepson, P. B., Li, S.-M., and Brickell, P. C.: The chemistry of biogenic hydrocarbons at a rural site in eastern Canada, J. Geophys. Res.-Atmos., 103, 2548725498, doi:10.1029/98JD01848, 1998.

Blake, R. S., Monks, P. S., and Ellis, A. M.: Proton-Transfer Reaction Mass Spectrometry, Chem. Rev., 109, 861-896, doi:10.1021/cr800364q, 2009.

Boeckelmann, A.: Monoterpene production and regulation in lavenders (Lavandula angustifolia and Lavandula $\mathrm{x}$ intermedia), available at: https://circle.ubc.ca/handle/2429/2804 (last access: 27 September 2013), 2008.

Chameides, W. L., Lindsay, R. W., Richardson, J., and Kiang, C. S.: The role of biogenic hydrocarbons in urban photochemical smog: Atlanta as a case study, Science, 241, 1473-1475, doi:10.1126/science.3420404, 1988.

Chiemchaisri, W., Visvanathan, C., and Jy, S. W.: Effects of trace volatile organic compounds on methane oxidation, Braz. Arch. Biol. Techn., 44, 135-140, doi:10.1590/S1516$89132001000200005,2001$.

Christian, T. J., Kleiss, B., Yokelson, R. J., Holzinger, R., Crutzen, P. J., Hao, W. M., Shirai, T., and Blake, D. R.: Comprehensive laboratory measurements of biomass-burning emissions: 2. First intercomparison of open-path FTIR, PTR-MS, and GC-MS/FID/ECD, J. Geophys. Res.-Atmos., 109, D02311, doi:10.1029/2003JD003874, 2004.

Ciccioli, P., Brancaleoni, E., Frattoni, M., Di Palo, V., Valentini, R., Tirone, G., Seufert, G., Bertin, N., Hansen, U., Csiky, O., Lenz, R., and Sharma, M.: Emission of reactive terpene compounds from orange orchards and their removal by withincanopy processes, J. Geophys. Res.-Atmos., 104, 8077-8094, doi:10.1029/1998JD100026, 1999.

Claeys, M., Graham, B., Vas, G., Wang, W., Vermeylen, R., Pashynska, V., Cafmeyer, J., Guyon, P., Andreae, M. O., Artaxo, P., and Maenhaut, W.: Formation of Secondary Organic Aerosols Through Photooxidation of Isoprene, Science, 303, 1173-1176, doi:10.1126/science.1092805, 2004.

Clarke, J. U.: Evaluation of censored data methods to allow statistical comparisons among very small samples with below detection limit observations, Environ. Sci. Technol., 32, 177-183, 1998.

Curci, G., Palmer, P. I., Kurosu, T. P., Chance, K., and Visconti, G.: Estimating European volatile organic compound emissions 
using satellite observations of formaldehyde from the Ozone Monitoring Instrument, Atmos. Chem. Phys., 10, 11501-11517, doi:10.5194/acp-10-11501-2010, 2010.

Darmais, S., Dutaur, L., Larsen, B., Cieslik, S., Luchetta, L., Simon, V., and Torres, L.: Emission fluxes of VOC by orange trees determined by both relaxed eddy accumulation and vertical gradient approaches, Chemosphere - Global Change Science, 2, 47-56, doi:10.1016/S1465-9972(99)00050-1, 2000.

da Silva, G., Graham, C., and Wang, Z.-F.: Unimolecular $\beta$ hydroxyperoxy radical decomposition with $\mathrm{OH}$ recycling in the photochemical oxidation of isoprene, Environ. Sci. Technol., 44, 250-256, 2009.

Davison, B., Taipale, R., Langford, B., Misztal, P., Fares, S., Matteucci, G., Loreto, F., Cape, J. N., Rinne, J., and Hewitt, C. N.: Concentrations and fluxes of biogenic volatile organic compounds above a Mediterranean macchia ecosystem in western Italy, Biogeosciences, 6, 1655-1670, doi:10.5194/bg-6-16552009, 2009.

De Gouw, J. and Warneke, C.: Measurements of volatile organic compounds in the earth's atmosphere using proton-transferreaction mass spectrometry, Mass Spectrom. Rev., 26, 223-257, 2006.

De Gouw, J. and Warneke, C.: Measurements of volatile organic compounds in the earth's atmosphere using proton-transferreaction mass spectrometry, Mass Spectrom. Rev., 26, 223-257, 2007.

Foken, T. and Wichura, B.: Tools for quality assessment of surfacebased flux measurements, Agric. Forest Meteorol., 78, 83-105, doi:10.1016/0168-1923(95)02248-1, 1996.

Forkel, R., Klemm, O., Graus, M., Rappenglück, B., Stockwell, W. R., Grabmer, W., Held, A., Hansel, A., and Steinbrecher, R.: Trace gas exchange and gas phase chemistry in a Norway spruce forest: A study with a coupled 1-dimensional canopy atmospheric chemistry emission model, Atmos. Environ., 40, Supplement 1, 28-42, doi:10.1016/j.atmosenv.2005.11.070, 2006.

Fuchs, H., Hofzumahaus, A., Rohrer, F., Bohn, B., Brauers, T., Dorn, H. P., Häseler, R., Holland, F., Kaminski, M., and Li, $\mathrm{X}$.: Experimental evidence for efficient hydroxyl radical regeneration in isoprene oxidation, Nat. Geosci., 6, 1023-1026, doi:10.1038/ngeo1964, 2013.

Fuentes, J. D., Gu, L., Lerdau, M., Atkinson, R., Baldocchi, D., Bottenheim, J. W., Ciccioli, P., Lamb, B., Geron, C., Guenther, A., Sharkey, T. D., and Stockwell, W.: Biogenic hydrocarbons in the atmospheric boundary layer: a review, B. Am. Meteorol. Soc., 81, 1537-1575, doi:10.1175/15200477(2000)081<1537:BHITAB>2.3.CO;2, 2000.

Genard-Zielinski, A.-C., Boissard, C., Fernandez, C., Kalogridis, C., Lathière, J., Gros, V., Bonnaire, N., and Ormeño, E.: Variability of BVOC emissions from a Mediterranean mixed forest in southern France with a focus on Quercus pubescens, Atmos. Chem. Phys. Discuss., 14, 17225-17261, doi:10.5194/acpd-1417225-2014, 2014.

Goldstein, A. H., Goulden, M. L., Munger, J. W., Wofsy, S. C., and Geron, C. D.: Seasonal course of isoprene emissions from a midlatitude deciduous forest, J. Geophys. Res.-Atmos., 103, 3104531056, doi:10.1029/98JD02708, 1998.

Griffin, R. J., Cocker, D. R., Flagan, R. C., and Seinfeld, J. H.: Organic aerosol formation from the oxidation of bio- genic hydrocarbons, J. Geophys. Res.-Atmos., 104, 3555-3567, doi:10.1029/1998JD100049, 1999.

Guenther, A. B., Jiang, X., Heald, C. L., Sakulyanontvittaya, T., Duhl, T., Emmons, L. K., and Wang, X.: The Model of Emissions of Gases and Aerosols from Nature version 2.1 (MEGAN2.1): an extended and updated framework for modeling biogenic emissions, Geosci. Model Dev., 5, 1471-1492, doi:10.5194/gmd-51471-2012, 2012.

Guenther, A., Hewitt, C. N., Erickson, D., Fall, R., Geron, C., Graedel, T., Harley, P., Klinger, L., Lerdau, M., Mckay, W. A., Pierce, T., Scholes, B., Steinbrecher, R., Tallamraju, R., Taylor, J., and Zimmerman, P.: A global model of natural volatile organic compound emissions, J. Geophys. Res.-Atmos., 100, 8873-8892, doi:10.1029/94JD02950, 1995.

Guenther, A. B., Zimmerman, P. R., Harley, P. C., Monson, R. K., and Fall, R.: Isoprene and monoterpene emission rate variability: Model evaluations and sensitivity analyses, J. Geophys. Res.Atmos., 98, 12609-12617, doi:10.1029/93JD00527, 1993.

Haase, K. B., Keene, W. C., Pszenny, A. A. P., Mayne, H. R., Talbot, R. W., and Sive, B. C.: Calibration and intercomparison of acetic acid measurements using proton-transfer-reaction mass spectrometry (PTR-MS), Atmos. Meas. Tech., 5, 27392750, doi:10.5194/amt-5-2739-2012, 2012.

Helsel, D. R. and Hirsch, R. M.: Statistical methods in water resources, Elsevier, available at: http://books.google.fr/books? $\mathrm{hl}=\mathrm{fr} \& \mathrm{lr}=\& \mathrm{id}=\mathrm{jao} 4 \mathrm{o} 5 \mathrm{X} 1 \mathrm{pvgC} \& \mathrm{oi}=\mathrm{fnd} \& \mathrm{pg}=\mathrm{PP} 2 \& \mathrm{dq}=\mathrm{Helsel}+$ and+Hirsch,+1992\&ots=QUPzeLd4J_\&sig=8nnOroZFkIJvnN_ wgKf3slP7tCQ (last access: 21 May 2014), 1992.

Holzinger, R., Sanhueza, E., Von Kuhlmann, R., Kleiss, B., Donoso, L., and Crutzen, P. J.: Diurnal cycles and seasonal variation of isoprene and its oxidation products in the tropical savanna atmosphere, Global Biogeochem. Cy., 16, 22-1-22-13, doi:10.1029/2001GB001421, 2002.

Horst, T. W.: A simple formula for attenuation of eddy fluxes measured with first-order-response scalar sensors, Bound.-Lay. Meteorol., 82, 219-233, doi:10.1023/A:1000229130034, 1997.

Jacob, D. J. and Wofsy, S. C.: Photochemistry of biogenic emissions over the Amazon forest, J. Geophys. Res.-Atmos., 93, 14771486, doi:10.1029/JD093iD02p01477, 1988.

Jenkin, M. E., Boyd, A. A., and Lesclaux, R.: Peroxy Radical Kinetics Resulting from the $\mathrm{OH}$-Initiated Oxidation of 1,3-Butadiene, 2,3-Dimethyl-1,3-Butadiene and Isoprene, J. Atmos. Chem., 29, 267-298, doi:10.1023/A:1005940332441, 1998.

Karl, T., Potosnak, M., Guenther, A., Clark, D., Walker, J., Herrick, J. D., and Geron, C.: Exchange processes of volatile organic compounds above a tropical rain forest: Implications for modeling tropospheric chemistry above dense vegetation, J. Geophys. Res., 109, D18306, doi:10.1029/2004JD004738, 2004.

Karl, T., Guenther, A., Yokelson, R. J., Greenberg, J., Potosnak, M., Blake, D. R., and Artaxo, P.: The tropical forest and fire emissions experiment: Emission, chemistry, and transport of biogenic volatile organic compounds in the lower atmosphere over Amazonia, J. Geophys. Res., 112, doi:10.1029/2007JD008539, 2007.

Karl, T., Guenther, A., Turnipseed, A., Tyndall, G., Artaxo, P., and Martin, S.: Rapid formation of isoprene photo-oxidation products observed in Amazonia, Atmos. Chem. Phys., 9, 7753-7767, doi:10.5194/acp-9-7753-2009, 2009.

Karl, T., Harley, P., Emmons, L., Thornton, B., Guenther, A., Basu, C., Turnipseed, A., and Jardine, K.: Efficient Atmospheric 
Cleansing of Oxidized Organic Trace Gases by Vegetation, Science, 330, 816-819, doi:10.1126/science.1192534, 2010.

Karl, T. G., Spirig, C., Rinne, J., Stroud, C., Prevost, P., Greenberg, J., Fall, R., and Guenther, A.: Virtual disjunct eddy covariance measurements of organic compound fluxes from a subalpine forest using proton transfer reaction mass spectrometry, Atmos. Chem. Phys., 2, 279-291, doi:10.5194/acp-2-279-2002, 2002.

Keenan, T., Niinemets, Ü., Sabate, S., Gracia, C., and Peñuelas, J.: Process based inventory of isoprenoid emissions from European forests: model comparisons, current knowledge and uncertainties, Atmos. Chem. Phys., 9, 4053-4076, doi:10.5194/acp-94053-2009, 2009.

Kesselmeier J. and Staudt M.: Biogenic Volatile Organic Compounds (VOC): An Overview on Emission, Physiology and Ecology, J. Atmos. Chem., 33, 23-88, 1998.

Kesselmeier, J., Bode, K., Schäfer, L., Schebeske, G., Wolf, A., Brancaleoni, E., Cecinato, A., Ciccioli, P., Frattoni, M., Dutaur, L., Fugit, J. L., Simon, V., and Torres, L.: Simultaneous field measurements of terpene and isoprene emissions from two dominant mediterranean oak species in relation to a North American species, Atmos. Environ., 32, 1947-1953, doi:10.1016/S13522310(97)00500-1, 1998

Kljun, N., Calanca, P., Rotach, M. W., and Schmid, H. P.: A Simple Parameterisation for Flux Footprint Predictions, Bound.-Lay. Meteorol., 112, 503-523, doi:10.1023/B:BOUN.0000030653.71031.96, 2004.

Kuhn, U., Andreae, M. O., Ammann, C., Araújo, A. C., Brancaleoni, E., Ciccioli, P., Dindorf, T., Frattoni, M., Gatti, L. V., Ganzeveld, L., Kruijt, B., Lelieveld, J., Lloyd, J., Meixner, F. X., Nobre, A. D., Pöschl, U., Spirig, C., Stefani, P., Thielmann, A., Valentini, R., and Kesselmeier, J.: Isoprene and monoterpene fluxes from Central Amazonian rainforest inferred from towerbased and airborne measurements, and implications on the atmospheric chemistry and the local carbon budget, Atmos. Chem. Phys., 7, 2855-2879, doi:10.5194/acp-7-2855-2007, 2007.

Laffineur, Q., Aubinet, M., Schoon, N., Amelynck, C., Mueller, J.F., Dewulf, J., Van Langenhove, H., Steppe, K., Simpraga, M., and Heinesch, B.: Isoprene and monoterpene emissions from a mixed temperate forest RID F-3549-2011, Atmos. Environ., 45, 3157-3168, doi:10.1016/j.atmosenv.2011.02.054, 2011.

Langford, B., Davison, B., Nemitz, E., and Hewitt, C. N.: Mixing ratios and eddy covariance flux measurements of volatile organic compounds from an urban canopy (Manchester, UK), Atmos. Chem. Phys., 9, 1971-1987, doi:10.5194/acp-9-1971-2009, 2009.

Langford, B., Misztal, P. K., Nemitz, E., Davison, B., Helfter, C., Pugh, T. A. M., MacKenzie, A. R., Lim, S. F., and Hewitt, C. N.: Fluxes and concentrations of volatile organic compounds from a South-East Asian tropical rainforest, Atmos. Chem. Phys., 10, 8391-8412, doi:10.5194/acp-10-8391-2010, 2010.

Laothawornkitkul, J., Taylor, J. E., Paul, N. D., and Hewitt, C. N.: Biogenic volatile organic compounds in the Earth system, New Phytol., 183, 27-51, 2009.

Lee, J. D., Lewis, A. C., Monks, P. S., Jacob, M., Hamilton, J. F., Hopkins, J. R., Watson, N., Saxton, J., Ennis, C., Carpenter, L. J., Fleming, Z. L., Bandy, B. J., Mills, G. P., Oram, D. E., Penkett, S. A., Slemr, J., Norton, E., Vaughan, G., Rickard, A. R., Whalley, L. K., Heard, D. E., Bloss, W. J., Gravestock, T., Johnson, G., Ingham, T., Smith, S. C., Seakins, P. W., Cryer, D., Stan- ton, J., Pilling, M. J., McQuaid, J. B., Jenkin, M. E., Utembe, S., Johnson, D., Coe, H., Bower, K., Gallagher, M., McFiggans, G., Carslaw, N., and Emmerson, K. M.: Ozone photochemistry during the UK heat wave of August 2003, Ozone photochemistry and elevated isoprene during the UK heatwave of August 2003, available at: https://lra.le.ac.uk/handle/2381/307 (last access: 21 November 2013), 2006.

Liu, Y. J., Herdlinger-Blatt, I., McKinney, K. A., and Martin, S. T.: Production of methyl vinyl ketone and methacrolein via the hydroperoxyl pathway of isoprene oxidation, Atmos. Chem. Phys., 13, 5715-5730, doi:10.5194/acp-13-5715-2013, 2013.

Makar, P. A., Fuentes, J. D., Wang, D., Staebler, R. M., and Wiebe, H. A.: Chemical processing of biogenic hydrocarbons within and above a temperate deciduous forest, J. Geophys. Res.-Atmos., 104, 3581-3603, doi:10.1029/1998JD100065, 1999.

McKinney, K. A., Lee, B. H., Vasta, A., Pho, T. V., and Munger, J. W.: Emissions of isoprenoids and oxygenated biogenic volatile organic compounds from a New England mixed forest, Atmos. Chem. Phys., 11, 4807-4831, doi:10.5194/acp-11-4807-2011, 2011.

Misztal, P. K., Nemitz, E., Langford, B., Di Marco, C. F., Phillips, G. J., Hewitt, C. N., MacKenzie, A. R., Owen, S. M., Fowler, D., Heal, M. R., and Cape, J. N.: Direct ecosystem fluxes of volatile organic compounds from oil palms in South-East Asia, Atmos. Chem. Phys., 11, 8995-9017, doi:10.5194/acp-11-89952011, 2011.

Misztal, P. K., Heal, M. R., Nemitz, E., and Cape, J. N.: Development of PTR-MS selectivity for structural isomers: Monoterpenes as a case study, Int. J. Mass Spectrom., 310, 10-19, doi:10.1016/j.ijms.2011.11.001, 2013.

Montzka, S. A., Trainer, M., Goldan, P. D., Kuster, W. C., and Fehsenfeld, F. C.: Isoprene and its oxidation products, methyl vinyl ketone and methacrolein, in the rural troposphere, J. Geophys. Res.-Atmos., 98, 1101-1111, doi:10.1029/92JD02382, 1993.

Miyoshi, A., Hatakeyama, S., and Washida, N.: OH radicalinitiated photooxidation of isoprene: An estimate of global CO production, J. Geophys. Res.-Atmos., 99, 18779-18787, doi:10.1029/94JD01334, 1994.

Navarro, M. A., Dusanter, S., Hites, R. A., and Stevens, P. S.: Radical Dependence of the Yields of Methacrolein and Methyl Vinyl Ketone from the OH-Initiated Oxidation of Isoprene under $\mathrm{NO}_{x}$-Free Conditions, Environ. Sci. Technol., 45, 923-929, doi:10.1021/es103147w, 2011.

Owen, S. M., Boissard, C., and Hewitt, C. N.: Volatile organic compounds (VOCs) emitted from 40 Mediterranean plant species:: VOC speciation and extrapolation to habitat scale, Atmos. Environ., 35, 5393-5409, doi:10.1016/S1352-2310(01)00302-8, 2001.

Park, J.-H., Goldstein, A. H., Timkovsky, J., Fares, S., Weber, R., Karlik, J., and Holzinger, R.: Eddy covariance emission and deposition flux measurements using proton transfer reaction - time of flight - mass spectrometry (PTR-TOF-MS): comparison with PTR-MS measured vertical gradients and fluxes, Atmos. Chem. Phys., 13, 1439-1456, doi:10.5194/acp-13-1439-2013, 2013.

Paulot, F., Crounse, J. D., Kjaergaard, H. G., Kürten, A., Clair, J. M. S., Seinfeld, J. H., and Wennberg, P. O.: Unexpected epoxide formation in the gas-phase photooxidation of isoprene, Science, 325, 730-733, 2009. 
Peeters, J. and Müller, J.-F.: $\mathrm{HO}_{\mathrm{x}}$ radical regeneration in isoprene oxidation via peroxy radical isomerisations. II: experimental evidence and global impact, Phys. Chem. Chem. Phys., 12, 1422714235, 2010.

Peeters, J., Nguyen, T. L., and Vereecken, L.: $\mathrm{HO}_{\mathrm{x}}$ radical regeneration in the oxidation of isoprene, Phys. Chem. Chem. Phys., 11, 5935-5939, 2009.

Richards, N. A. D., Arnold, S. R., Chipperfield, M. P., Miles, G., Rap, A., Siddans, R., Monks, S. A., and Hollaway, M. J.: The Mediterranean summertime ozone maximum: global emission sensitivities and radiative impacts, Atmos. Chem. Phys., 13, 2331-2345, doi:10.5194/acp-13-2331-2013, 2013.

Rinne, H. J. I., Guenther, A. B., Warneke, C., de Gouw, J. A., and Luxembourg, S. L.: Disjunct eddy covariance technique for trace gas flux measurements, Geophys. Res. Lett., 28, 3139-3142, doi:10.1029/2001GL012900, 2001.

Rinne, H. J. I., Guenther, A. B., Greenberg, J. P., and Harley, P. C.: Isoprene and monoterpene fluxes measured above Amazonian rainforest and their dependence on light and temperature, Atmos. Environ., 36, 2421-2426, doi:10.1016/S1352-2310(01)00523-4, 2002.

Rinne, J., Markkanen, T., Ruuskanen, T. M., Petäjä, T., Keronen, P., Tang, M.J., Crowley, J. N., Rannik, Ü., and Vesala, T.: Effect of chemical degradation on fluxes of reactive compounds - a study with a stochastic Lagrangian transport model, Atmos. Chem. Phys., 12, 4843-4854, doi:10.5194/acp-12-4843-2012, 2012.

Ruppert, L. and Heinz Becker, K.: A product study of the $\mathrm{OH}$ radical-initiated oxidation of isoprene: formation of $\mathrm{C}_{5}$-unsaturated diols, Atmos. Environ., 34, 1529-1542, doi:10.1016/S1352-2310(99)00408-2, 2000.

Schmidt, H., Derognat, C., Vautard, R., and Beekmann, M.: A comparison of simulated and observed ozone mixing ratios for the summer of 1998 in Western Europe, Atmos. Environ., 35, 62776297, doi:10.1016/S1352-2310(01)00451-4, 2001.

Seufert, G., Bartzis, J., Bomboi, T., Ciccioli, P., Cieslik, S., Dlugi, R., Foster, P., Hewitt, C. N., Kesselmeier, J., Kotzias, D., Lenz, R., Manes, F., Pastor, R. P., Steinbrecher, R., Torres, L., Valentini, R., and Versino, B.: An overview of the Castelporziano experiments, Atmos. Environ., 31, Supplement 1, 5-17, doi:10.1016/S1352-2310(97)00334-8, 1997.

Simon, V., Dumergues, L., Bouchou, P., Torres, L., and Lopez, A.: Isoprene emission rates and fluxes measured above a Mediterranean oak (Quercus pubescens) forest, Atmos. Res., 74, 49-63, doi:10.1016/j.atmosres.2004.04.005, 2005.

Singer, W., Beauchamp, J., Herbig, J., Dunk1, J., Kohl, I., and Hansel, A.: Dynamic gas dilution system for accurate calibration of analytical instruments such as ptr-ms, in 3rd International Conference on Proton Transfer Reaction Mass Spectrometry and Its Applications, IUP Conference Series, 232-234., 2007.

Spirig, C., Neftel, A., Ammann, C., Dommen, J., Grabmer, W., Thielmann, A., Schaub, A., Beauchamp, J., Wisthaler, A., and Hansel, A.: Eddy covariance flux measurements of biogenic VOCs during ECHO 2003 using proton transfer reaction mass spectrometry, Atmos. Chem. Phys., 5, 465-481, doi:10.5194/acp-5-465-2005, 2005.
Strong, C., Fuentes, J. D., and Baldocchi, D.: Reactive hydrocarbon flux footprints during canopy senescence, Agr. Forest Meteorol., 127, 159-173, 2004.

Stroud, C., Makar, P., Karl, T., Guenther, A., Geron, C., Turnipseed, A., Nemitz, E., Baker, B., Potosnak, M., and Fuentes, J. D.: Role of canopy-scale photochemistry in modifying biogenicatmosphere exchange of reactive terpene species: Results from the CELTIC field study, J. Geophys. Res.-Atmos., 110, D17303, doi:10.1029/2005JD005775, 2005.

Szopa, S., Foret, G., Menut, L., and Cozic, A.: Impact of large scale circulation on European summer surface ozone and consequences for modelling forecast, Atmos. Environ., 43, 11891195, doi:10.1016/j.atmosenv.2008.10.039, 2009.

Taipale, R., Ruuskanen, T. M., Rinne, J., Kajos, M. K., Hakola, H., Pohja, T., and Kulmala, M.: Technical Note: Quantitative long-term measurements of VOC concentrations by PTR-MS measurement, calibration, and volume mixing ratio calculation methods, Atmos. Chem. Phys., 8, 6681-6698, doi:10.5194/acp8-6681-2008, 2008.

Taipale, R., Ruuskanen, T. M., and Rinne, J.: Lag time determination in DEC measurements with PTR-MS, Atmos. Meas. Tech., 3, 853-862, doi:10.5194/amt-3-853-2010, 2010.

Trainer, M., Williams, E. J., Parrish, D. D., Buhr, M. P., Allwine, E. J., Westberg, H. H., Fehsenfeld, F. C., and Liu, S. C.: Models and observations of the impact of natural hydrocarbons on rural ozone, Nature, 329, 705-707, doi:10.1038/329705a0, 1987.

Tsigaridis, K. and Kanakidou, M.: Global modelling of secondary organic aerosol in the troposphere: a sensitivity analysis, Atmos. Chem. Phys., 3, 1849-1869, doi:10.5194/acp-3-1849-2003, 2003.

Tuazon, E. C. and Atkinson, R.: A product study of the gas-phase reaction of Isoprene with the $\mathrm{OH}$ radical in the presence of $\mathrm{NO}_{\mathrm{x}}$, Int. J. Chem. Kinet., 22, 1221-1236, doi:10.1002/kin.550221202, 1990.

Velentini, R., Greco, S., Seufert, G., Bertin, N., Ciccioli, P., Cecinato, A., Brancaleoni, E., and Frattoni, M.: Fluxes of biogenic VOC from Mediterranean vegetation by trap enrichment relaxed eddy accumulation, Atmospheric Environment, 31, Supplement 1, 229-238, doi:10.1016/S1352-2310(97)00085-X, 1997.

Wuebbles, D. J., Grant, K. E., Connell, P. S., and Penner, J. E.: The Role of Atmospheric Chemistry in Climate Change, JAPCA J. Air. Waste Ma., 39, 22-28, doi:10.1080/08940630.1989.10466502, 1989.

Yuan, B., Hu, W. W., Shao, M., Wang, M., Chen, W. T., Lu, S. H., Zeng, L. M., and Hu, M.: VOC emissions, evolutions and contributions to SOA formation at a receptor site in eastern China, Atmos. Chem. Phys., 13, 8815-8832, doi:10.5194/acp-13-88152013, 2013. 